Review

\title{
Governing Transitions towards Sustainable Agriculture-Taking Stock of an Emerging Field of Research
}

\author{
Inga C. Melchior and Jens Newig *(D) \\ Research Group Governance, Participation and Sustainability, Leuphana University Lüneburg, \\ 21335 Lüneburg, Germany; lg070887@stud.leuphana.de \\ * Correspondence: newig@uni.leuphana.de
}

check for updates

Citation: Melchior, I.C.; Newig, J.

Governing Transitions towards Sustainable Agriculture-Taking Stock of an Emerging Field of

Research. Sustainability 2021, 13, 528. https://doi.org/10.3390/su13020528

Received: 29 October 2020

Accepted: 31 December 2020

Published: 8 January 2021

Publisher's Note: MDPI stays neutral with regard to jurisdictional clai$\mathrm{ms}$ in published maps and institutional affiliations.

Copyright: $\odot 2021$ by the authors. Licensee MDPI, Basel, Switzerland. This article is an open access article distributed under the terms and conditions of the Creative Commons Attribution (CC BY) license (https:// creativecommons.org/licenses/by/ $4.0 /)$.

\begin{abstract}
The need for fundamental changes in the way humans interact with nature is now widely acknowledged in order to achieve sustainable development. Agriculture figures prominently in this quest, being both a major driver and a major threat to global sustainability. Agricultural systems typically have co-evolved with other societal structures-retailers, land management, technology, consumer habits, and environmental and agricultural law-and can therefore well be described as socio-technical regimes in the sense of the sustainability transitions literature. This paper aims to give an overview of the emerging field of governing transitions to sustainability agriculture and the topics and trends covered, focusing on how agricultural transitions are being governed through a variety of actors and at a variety of levels. We conduct a systematic review of 153 articles published before the year 2019. We identify two main perspectives: papers that analyse the status quo in farming practices and reasons for lock-in, and papers that explore potential transition pathways and their governance. Predominantly, papers study (local) niche developments and discuss governance options for upscaling, rather than actual regime change. Seven distinct perspectives emerge from our reading of the selected articles: application of theoretical perspectives from the literature on socio-technical transitions; governance and regulation; knowledge and learning; concrete approaches to reduce the environmental impact of agricultural systems; urbanisation, urban agriculture, and local food networks; the role of agri-food businesses; as well as the role of gender. While a variety of local case studies shows potential for small-scale changes that might be transferable to other regions and higher levels of governance, it generally appears that more integrative, comparative work and perhaps more coherence in conceptual approaches would benefit the currently highly fragmented field.
\end{abstract}

Keywords: sustainable agriculture; sustainability governance; sustainability transitions; regime change; niche developments; upscaling

\section{Introduction}

The need for fundamental changes in the way humans interact with nature is now widely acknowledged in order to achieve sustainable development [1]. Agriculture figures prominently in this quest [2,3]. Agriculture is both a major driver and a major threat to global sustainability (cf. [4]). While playing a key role for food security against the background of ongoing population growth and increasing demands for food [5], this has at the same time helped unsustainable agricultural practices to evolve and establish [6]. These long-term trends such as the intensification of high-input agricultural crop and livestock production depending on external intakes of nutrients and pesticides jeopardise sustainability by causing biodiversity losses, land-use changes and deforestation, and the contamination of water bodies (cf. [6-8]). Global trends such as population growth happening simultaneously as the depletion of resources and degradation of ecosystem services in the era of the Anthropocene require fundamental changes in land use and management practices and responsible governance of global common resources in order to 
increase agricultural resilience $[4,8-10]$. These ongoing developments indicate the need of "repositioning world agriculture from its current role as the world's single largest driver of global environmental change, to becoming a critical agent of a world transition to global sustainability within the biophysical safe operating space on Earth" [2] (p. 6). These needs are anchored in the second Sustainable Development Goal (SDG), which sets the frame for future agricultural development by 2030 by stressing the need to achieve food security and resilient agricultural systems that help to preserve ecosystems instead of degrading them [11].

Agricultural systems are part of larger food systems and typically have co-evolved with other societal structures-retailers, land management, technology (e.g., precision farming), consumer habits (e.g., meat consumption), and environmental and agricultural law such as the European Union Common Agricultural Policy. Agricultural systems can therefore well be described as socio-technical regimes in the sense of the "sustainability transitions" literature (cf. [12-15]). In this literature, sustainability transitions are commonly understood as long-term processes of fundamental and far-reaching regime change from a less sustainable to a more sustainable state, where socio-technical regimes refer to co-evolved dominant industries or otherwise institutionalised practices, characterised by "lock-in", such that the different regime elements (e.g., policies, practices, technologies, knowledge, or values) stabilise each other, making change a challenging task. While for other sectors, notably energy, a whole transitions sub-literature has developed, this degree of consolidation is not yet observable for agriculture. All the more we feel it is important to take stock of the emerging field of transitions to sustainability agriculture and the topics and trends covered. Existing reviews analyse literature on agro-food sustainability transitions in relation to research themes identified by the Sustainability Transitions Research Network [16], or focus on food systems as a whole [17]. The aim of this review is to take stock of current literature on sustainable transitions to sustainable agriculture by identifying thematic clusters and priorities from the literature. Thus, many observations have an illustrative character evincing manifold approaches and are not intended to provide general conclusions considering the limited amount of literature in the field. Furthermore, the use of theoretical perspectives especially from the literature on socio-technical transitions is analysed.

\section{Materials and Methods}

Relevant literature was identified by using the combined search string "TITLE (agri* OR agro* OR farm*) AND TITLE-ABS-KEY (sustainab* W/3 (transition* OR transformat*)) AND (LIMIT-TO (DOCTYPE, "ar") OR LIMIT-TO (DOCTYPE, "re") OR LIMIT-TO (DOCTYPE, "ip"))" in the database Scopus. The search yielded 197 results (10 April 2019). After screening all abstracts, the number of papers considered in this review was limited to 153 according to the following exclusion criteria. Literature without relevance for this article's topic on sustainability transitions or transformations in agriculture, not available in full text, or written in a language other than English or German were excluded. The sample was limited to literature published until the year 2018 (including literature published first online in 2018 with an "in press" status by the date of the search). The review has a global scope. A list of all considered publications can be found in Appendix A.

\section{Characteristics of the Identified Literature}

The 153 articles considered in this paper were published between 1988 and 2018. Especially within the last five years, a huge increase in the number of publications on sustainability transitions in the agricultural sector can be observed (Figure 1). More than two-thirds of the publications considered have been published since 2014, with $29 \%$ of the publications just in the year 2018. The field of authors is very heterogeneous with only one author having published four and eight authors with three contributions respectively. The studied literature was published in 84 different journals, around $10 \%$ in Sustainability. Other journals being represented with five or more published contributions are Agroecology 
and Sustainable Food Systems, Agriculture and Human Values, Journal of Cleaner Production, and Land Use Policy (Figure 2).

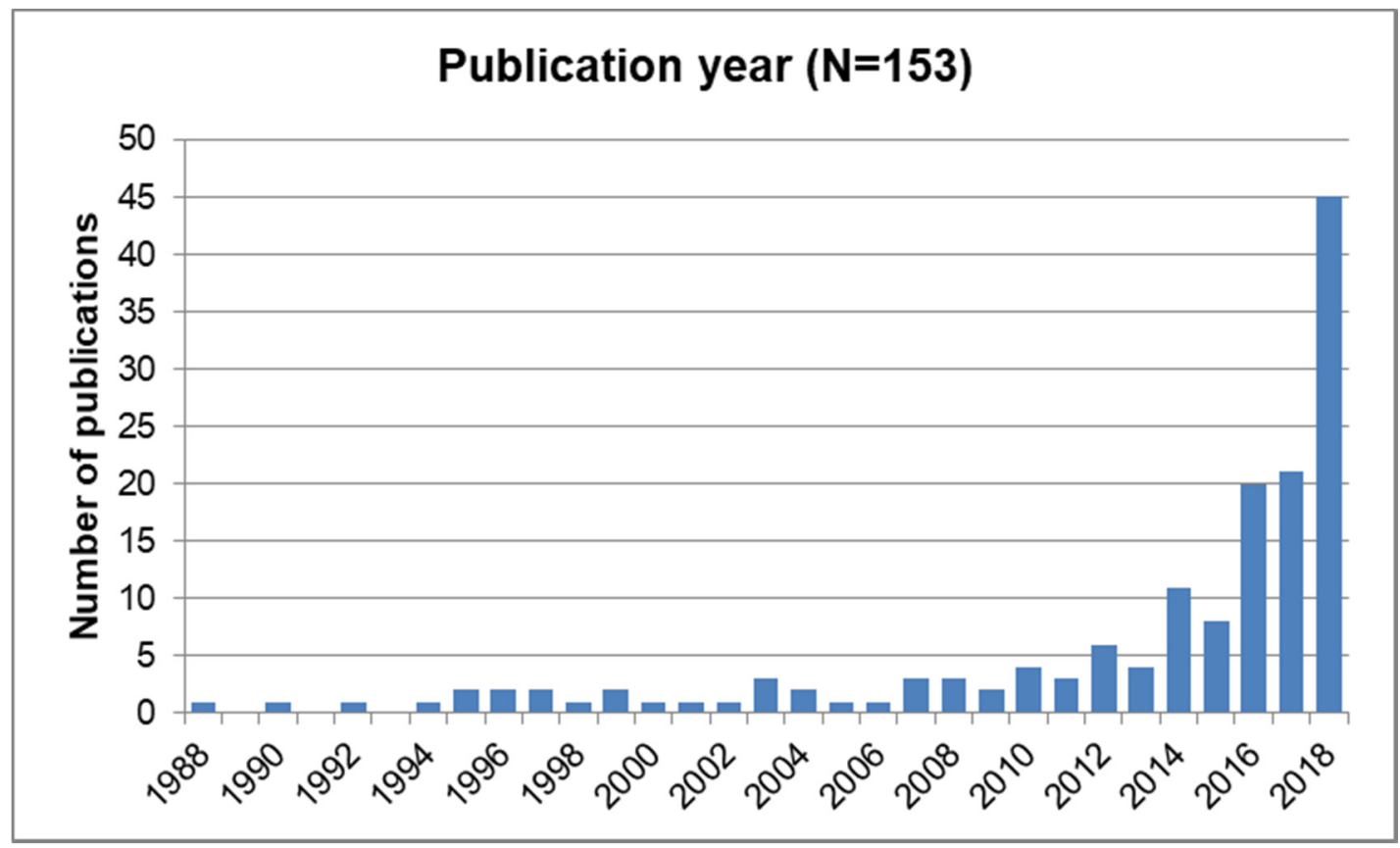

Figure 1. Publication years of the 153 considered publications in the sample.

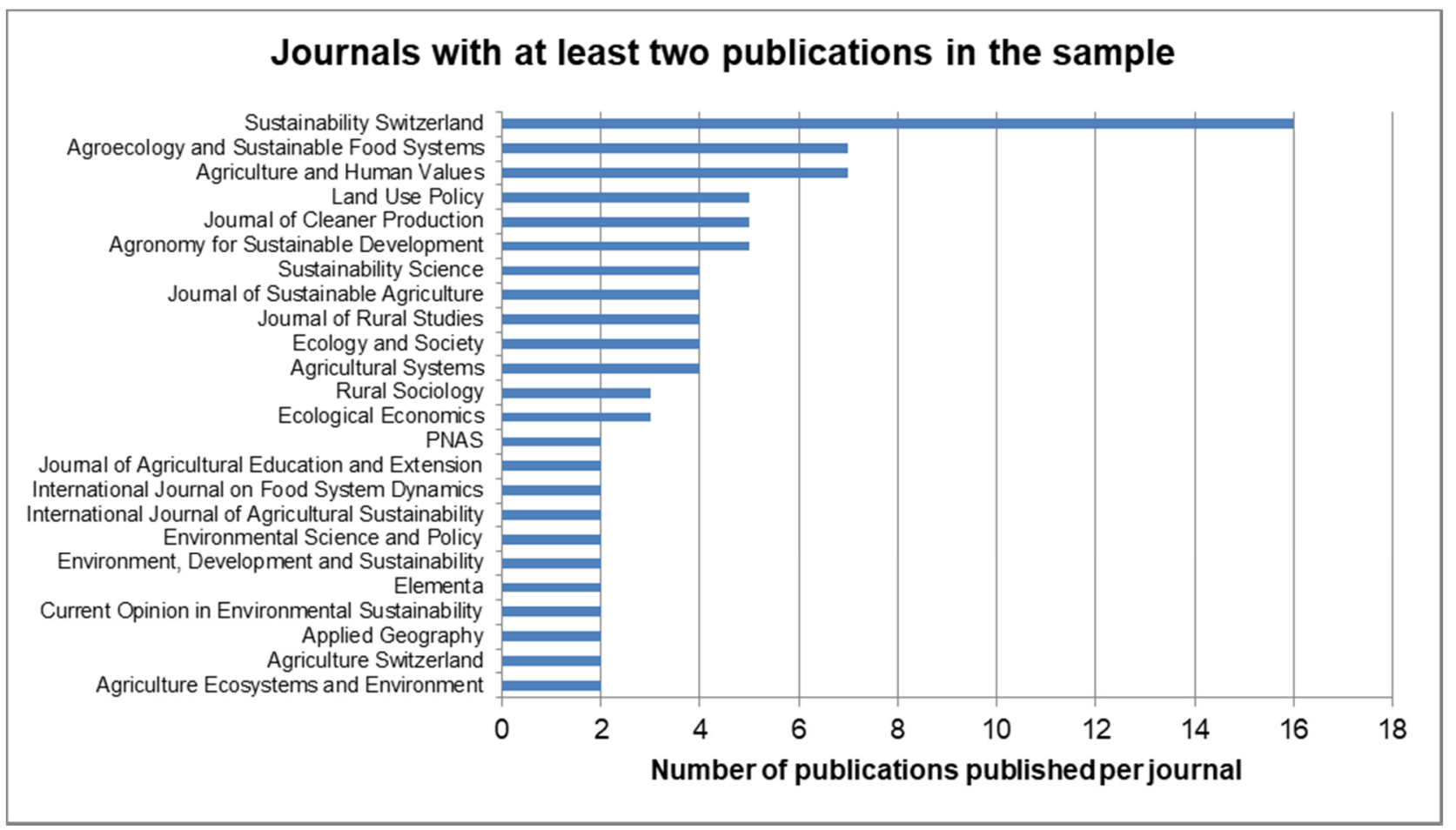

Figure 2. Journals that published two or more publications considered in this review.

Overall, there appears a broad consensus in the reviewed literature on the necessity of a transformation in the agricultural sector. The awareness of a variety of practices causing adverse effects stresses the need for change. Examples are industrial pig production resulting in areas with high population density and an increased risk of diseases besides 
other ecological problems [18]; the rather recent transformation to industrialised commercial agricultural systems in countries like Laos commonly using monocultures leading to the degradation of soils and nutrient loss [19]; agricultural innovations with unintended unsustainable side effects [20]; and inefficient irrigation systems and colonial patterns in commodity agriculture [21]. This agricultural transformation takes place in the context of changing conditions due to global environmental and climate change not least driven also by agriculture itself [2,22], negative impacts of current agricultural practices on ecosystems as already mentioned, as well as global trends such as population growth posing great challenges to food security and distribution [23,24].

However, starting from this relatively common point of departure, the foci of investigations on transitions in agriculture vary hugely both in terms of content and geographical focus. Most studies on sustainability transitions in agriculture have a geographical focus on one or several countries or a whole region (Figure 3). Countries from various income groups and from all continents are represented, however, to very different extents. Nine studies have a global focus, 34 feature North America, nearly one-third (50) of the studies are located European countries and regions, 21 in Asia, 16 in Latin America, 9 in Africa, and 6 in Australia and Oceania. Fifteen studies have no geographical focus.

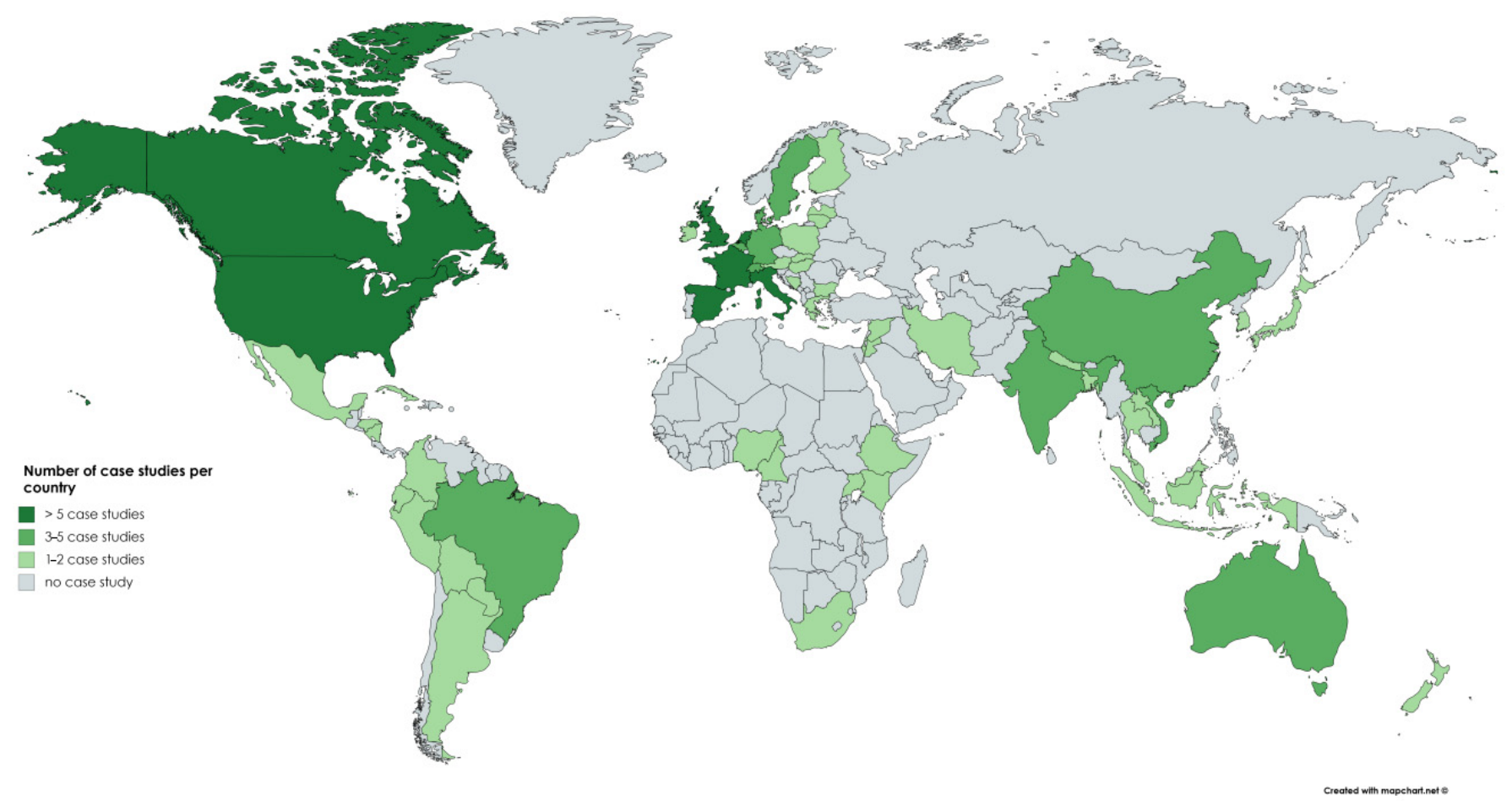

Figure 3. Overview of local case studies ( $\mathrm{N}=138)$. Some further empirical studies refer to continents (Africa (1), Asia (1), Europe (3)) or regions (European Union (2)). Multiple counts per paper possible.

Differences in regional characteristics shape the foci of studies: regions e.g., in Europe, the United States, and Latin America are studied, where industrialised agricultural systems prevail (cf. [25-27]). In countries such as Ethiopia where agricultural systems are shaped differently, questions about future development in the agricultural sector are strongly related to food security, economic growth, and issues of poverty [28]. Furthermore, a transformation of agricultural practices can reduce dependence and vulnerability as shown in the Yangou watershed in China [29]. It is noticeable that a majority of early case studies on sustainable agriculture in the beginning of the 1990s took place in Canada [30-32]. Furthermore, the focus of articles shifted over time: while early articles looked at sustainable agriculture in the context of population size with a clear focus on sustainable growth $[23,33]$ and have been closely linked to questions of socio-economic development [34], these topics 
seem no longer dominating the field of research. While they are still present especially in studies on the Global South, ecological issues (in conjunction with social aspects) are now in the foreground and analysed from various perspectives. It is especially interesting to view these descriptive results against the background of a review of empirical studies focusing on agroecology by Gómez et al. [35] (p. 361), who stress prevailing "colonial patterns in the production, distribution, and acquirement of knowledge". Furthermore, although the necessity of systemic approaches in agroecology has been stated, a tendency towards disciplinary research on particular aspects remains [35] (p. 361).

While a multitude of papers analyse historical or current trajectories in farming practices to assess the status quo or lock-in structures (cf. [28,36-40]), an approach often used to explore alternative futures or design transformative actions is the construction and analysis of scenarios, and potential future pathways [32,41-45]. Plumecocq et al. [46] emphasise that there may be more than one possible transition pathway towards sustainable agriculture.

\section{Thematic Foci of the Literature on Sustainability Transitions in Agriculture}

The studied papers cover research undertaken in many different subfields of agriculture or located at the interface of agriculture and other sectors. We identified seven thematic clusters in the literature on transitions in agriculture. These will be presented below, starting with a discussion on how agricultural regimes and their transition towards sustainability are conceptualised in the studied papers.

\subsection{Application of Theoretical Perspectives from the Socio-Technical Transitions Literature}

To investigate the dynamics of sustainability transitions in agriculture, nearly onefourth of the considered publications explicitly refers to concepts from the socio-technical transitions literature. Three transitions-related theoretical approaches are repeatedly referred to in our sample. This is, first and foremost, the Multi-Level Perspective on sociotechnical transitions (MLP), which is also "increasingly complemented" with other concepts [47] (p. 1714) (for examples see [20,28,45]). The MLP conceptualises transitions as interactions of three "levels" of relative stability: niche, regime, and landscape. Fundamental change of the dominant regime is explained inter alia by pressure from (experimental) niche innovations on one hand, and by pressure from the landscape level on the other hand, which represents the more slowly changing (political, societal) regime context. Second, Strategic Niche Management (SNM) [48] has been developed as a governance approach to foster innovation in niches "as protected spaces, i.e., specific markets or application domains, in which radical innovations can develop without being subject to the selection pressure of the prevailing regime" [49] (p. 957). Third, Transition Management (TM) [50,51] was introduced as a prescriptive governance approach, building on complex systems theory, stakeholder collaboration, and vision-building [50].

While SNM and TM are mentioned three and twelve times, respectively, the MLP clearly is the most commonly used concept, especially to investigate niches or niche innovations and how these make an impact on the dominant regime. This observation is in line with results from El Bilali [47], who analysed how literature on sustainability transitions of agro-food systems uses five transition theory frameworks including the MLP, TM, and SNM as well as innovation systems and the Social Practices Approach. He proposes to integrate these frameworks into one that is specifically targeted at the analysis of agro-food systems [47].

Various papers refer to how regimes are understood in the socio-technical transitions literature (cf. [39,52-58]). Although many papers use this conceptual regime term, only some explicitly concretise what they actually understand as the current regime. However, among those who do, there seems to be wide agreement on characterising the dominant sociotechnical system in agriculture as neoliberal, productivist, and industrial agribusiness supported by political incentives and focusing on markets [40,54,59-62]. While this regime type has been criticised for its adverse environmental, social, and economic impacts [63], Huttunen and Oosterveer [64] (p. 192) emphasise that "[i]n a sustainable 
production regime environmental and social issues related to farming are regarded as equally important as economic issues".

Very few papers explicitly aim to contribute to the conceptual literature on sustainability transitions. For example, Bui et al. [53] (p. 102) deeply engage with the multi-level perspective to study how local niche initiatives trigger regime change and "highlight [ ... ] the crucial role of local authorities in regime configuration processes". Ollivier et al. [65] investigate whether socio-technical transition and socio-ecological systems can be adequately applied to analyse agroecological transitions. Thereby, they point out some special requirements differing from the analysis of other transitions such as "enrolling multiple and relatively isolated decision makers as well as nonhuman entities" [65] (p. 2) and "suggest [to] break [ ... ] away from a systematic ordering of the different transition levels in established models, the better to explore, in practice, the range of levels involved and the diversity of relationships between them, as well as their synergies" in order to account for other types of interactions [65] (p. 13). Martin et al. [66] (p. 14) investigate how the three research approaches of "simulation modelling", "comprehensive analysis", and "codesign" relate to each other and argue that they "should be combined iteratively" to create knowledge on the whole transition process.

Several case studies look at local niche innovations and the potential for upscaling these and shape regimes towards sustainable agriculture (cf. [55,60]), whereas Wigboldus et al. [20] (p. 14) propose that current scaling methods "such as dissemination, diffusion, adoption and transfer of technologies and practices" insufficiently consider the complexity of wider contexts and, thus, hinder "effective and responsible" upscaling. Using a "territorial approach", "starting from the territory (and the diversity of initiatives) instead of starting from specific initiatives studied in isolation", Lamine et al. [67] (p. 162) outline the potential of various initiatives complementing each other to foster a sustainability transition in a certain territory. An investigation of different narratives of development trajectories and the likelihood of different scenarios in Ethiopian agriculture by combining the MLP with approaches from social-ecological transformations and institutional entrepreneurship highlights the strong role of the authoritarian Ethiopian government that predominantly maintains a growth narrative and hence the limited possibility for niche actors to challenge the incumbent regime [28]. Remarkably, Vankeerberghen and Stassart [39] (p. 402) do not assume the niche of conservation agriculture in Wallonia in Belgium to evolve outside the regime with the aim of mainstreaming, but rather, that it evolves from inside it, "progressively detaching itself from the regime", evoking changes in farmers' perception of soil that might initiate further steps towards sustainability. They call this process "insularization" [39].

Social innovation is not restricted to niches but might come about "in the interaction with the regime rules, as an effort to maintain value-oriented activities" as shown in the case of seasonal food markets in Montreal [52] (p. 13). Here, niche development does not happen completely separate from the regime because innovations have to adapt to its rules [52]. "Learning and Innovation Networks for Sustainable Agriculture" (LINSA) in various parts of Europe are studied as niche initiatives that supposedly challenge the dominant "productivist regime" [54] (p. 56). Thereby, regime compatibility is seen as the main variable for the diffusion of niche innovations that, however, does not necessarily coincide with potential influence on the regime as "[t]he relationship between compatibility and the ability, and willingness, of LINSA actors to exploit regime tensions also affects diffusion" [54] (p. 65). Stating that governance of transitions is not sufficiently considered in the MLP, the role of multi-stakeholder initiatives (MSIs) in the governance of agricultural transitions in the USA is examined [58]. The MSIs investigated have been dominated by "lead regime actors" from agribusiness and their interests; they are seen to bear potential for small-scale improvements towards sustainability but lack the ability to achieve a fundamental regime change [58] (p. 629).

Several papers mention "window(s) of opportunity" offering space for the niche development and a transition towards a sustainable agricultural and food system $[20,28,52,58,60,62,63]$. Identified factors opening up windows of opportunity were the cow disease bovine spongi- 
form encephalopathy (BSE) [62] and changed regulations for trade under the European Union's Common Agricultural Policy [60].

Few papers deeply engage with TM (cf. [52,68,69]). For example, TM may be used "to structure the evaluation of the process and the analysis of the participating actors" and the impacts of sustainability experiments [69] (p. 3). To analyse pathways for change in agricultural systems, Dentoni et al. [70] use a perspective of large systems change (LSC) as a wider approach than as insufficiently criticised co-creation strategies of TM. Although the focus of the case study is on modernisation rather than sustainability, some conceptual aspects how the concept of transition management might be adapted and broadened are highlighted by Grin [68]. These include pointing out that learning may take place during the "take-off stage" as well as the "acceleration stage" of transitions, considering a wider range of actors, and develop manifold transition pathways [68] (p. 84).

Except for El Bilali [47], who analyses the use of SNM in research, no paper from our sample deeply engages with SNM, which seems to confirm its standing as "a marginal framework in research on agro-food sustainability transitions" [47] (p. 18). This finding could be interpreted in two different ways. First, it could be that for sustainability transitions in agriculture, technological niche innovations play a less decisive role (as compared, for example, to energy regimes). However, the many cases identified in this review tell a different story. Local innovations-albeit less of a technological nature-and their potential upscaling appear to dominate the field. Hence, another interpretation could be that literature does not frame these processes in SNM terms-which would tell less about agricultural transitions as such but about the way concepts travel within and across research communities.

\subsection{Politics, Regulations and Public Funding, Governance and Participation}

The political circumstances covered in the studied literature are manifold and the topics vary both geographically and related to content. Literature considered from the early 1990s mainly identifies policy needs to transform agriculture sustainably (see [30,31]). For example, Pretty [71] claims a need for political reforms to allow sustainable intensification approaches to unfold at a greater scale. Guthman [72] emphasises the impact and dominance of the current neoliberalist paradigm on the development of a philanthropic approach towards transforming the Californian food system towards sustainability. She argues that the predominance of neoliberal thinking prevented actors from questioning the paradigm itself; however, these explored doable changes within a neoliberal system [72]. An analysis of power dimensions in an industrialised and an indigenous food system in Bolivia concludes that democratisation is key to uncover power relations and enable participation and, thus, create opportunities for sustainable food production as seen in the local indigenous community [26] (p. 23).

Public funding in favour of sustainable agriculture is an aspect given much emphasis. Öhlund et al. [73] analyse the use of funding schemes of the European Union's Common Agricultural Policy (CAP) in Sweden and Poland with regard to sustainable agriculture and find these to have a huge influence on the form of agricultural practices. As only very few of the CAP funding schemes directly address sustainability of the whole socialecological system, "there is no transformative ambition or impetus for change towards a more sustainable agricultural production system embedded in the support schemes" [73] (p. 284). Furthermore, there might be unused potential with regard to more sustainable practices that take the individual characteristics of a certain social-ecological system into account as the CAP does not provide much space for adaptation to the local context but rather endangers local sustainable solutions [73] (p. 284). Gaudino et al. [41] argue that financial incentives through the EU's greening policies do not lead to the desired effects as they are voluntary and often only used by farms that already engage in sustainable agriculture while others consider them not rewarding enough to fundamentally change their business model and thus profits. To change this, they claim that EU regulations are required [41]. With regard to attitudes towards a payment for ecosystem services 
(PES) policy scheme in Thailand, Kanchanaroek and Aslam [74] conclude that despite a general interest, incentives for most farmers to change their practices in a radical way that would favour sustainability are rather low and that schemes should be more flexible to increase participation. An investigation of the amount of public funding by the US Department of Agriculture (USDA) Research, Extension \& Economics (REE) Mission Area for agroecological research projects that started in 2014 yields similar results [75,76]. It outlines that funding amounts directed towards sustainable agriculture are small, and even lower for "systems-based agroecology research" [75] (p. 272). The latter is seen to be key for triggering systems change and its funding should therefore be increased [75,76]. Financial means within the scope of agricultural aid in countries of the global south support unsustainable practices and bar the way to progress towards sustainability, which may be illustrated with the case of the UK agricultural development aid where the share of financial means dedicated to agroecological projects has been below 5\% since 2010 [77].

Taking stock of complex networks with a variety of actors involved in steering the sustainability of food and farming systems, aspects of governance and participation are widely discussed in the literature. The development of institutional settings accomplished by multiple stakeholder groups to enable the implementation of sustainable agricultural programs may prove even more challenging than implementing the programs itself and requires linkages within and between various organisational scales as shown in an example from Bosnia and Herzegovina [78]. In cases in Italy, Greece, and Spain, "better networking and engagement of different actors within a coherent institutional framework supporting the transition" were found to be crucial to foster agroecology [79] (p. 18). Cross and Ampt [59] find a profound bottom-up contribution to agroecology from a movement in Australia that engages in the regeneration and sustainable management of native grasslands, and which they characterise as a "community of practice". A key question examined is why farmers do or do not take part in the transition towards sustainable agriculture and which motives and intentions drive their actions. With regard to rural transitions in the context of the CAP, implementation barriers are found "at the level of individual businesses and in respect of awareness, understanding and the confidence to act" [80] (p. 43). Honig et al. [81] point towards the importance of understanding and considering farmers' value systems that influence why and how they transition in the design of policies, while Coquil et al. [82] find that transitions start when farmers become aware of gaps between their beliefs and actions. To understand how cultural politics hinders individuals to transition to sustainable agriculture, Meek [83] (p. 287) argues that investigating "the constant interplay between environmental, cognitive, and relational mechanisms that shape these spatialized cultural politics" is key.

\subsection{Knowledge and Learning}

Knowledge, education, and learning processes aiming at agricultural sustainability and the parts various actors play in these are discussed. Grin [68] stresses the necessity of an ongoing learning process during various stages of a transition. An analysis of agricultural advisors' knowledge of sustainable soil management in the UK finds profound theoretical knowledge but calls for an increase in practical knowledge and a standardisation to correspond to new policy requirements [84]. Furthermore, "learning competence" is found to be necessary to be able to benefit from technological innovations [85].

Martin et al. [66] (p. 3) outline three research approaches, namely, "comprehensive analysis, co-design, and simulation modelling" that might complement each other and bear potential for agronomy to support sustainable agricultural development. Regarding education, Rasmussen and Kaltoft [86] point out that attitudes of lecturers and students in higher agricultural education towards sustainable agricultural practices highly diverge and call for making different values explicit to allow for critical reflection. They find attitudes to differ by age and gender with older students and females being more favourable towards alternative agriculture [86]. Ahmed et al. [87] (p. 13) argue that experiential learning approaches "bridging primary scientific research with undergraduate education focused on 
identifying and implementing sustainability solutions" can be a contribution to educating and encouraging students to engage in the sustainability transformation of the food system after graduating. Massicotte and Kelly-Bisson [61] (p. 582) find "that permaculture instruction [in the eastern part of Ontario in Canada] has been and remains deeply embedded within market and colonial relations" reproducing these structures in practice and stress the need to collaborate, among others, with Indigenous and local organisations. Learning can also take place by testing alternative food practices until approaches seem promising and might become applicable to a broader scale as shown in the case of self-organisation of agroecology in food movements in Ecuador, where practices can trigger transitions by bypassing formal institutions [88] (pp. 13-14). The results of a model small farm enterprise two decades ago, which aimed at learning together about the local agroecosystem, taking stock of concerns and identifying local leverage points for sustainability transitions, show that actors such as universities may support transformations by enabling local actors and communities to take a systemic perspective [89]. In a similar vein, participatory learning processes in research might contribute to an agricultural transition [90,91].

Considering various knowledge types is emphasised. Šūmane et al. [92] assess different trajectories of modernising farms and investigate the role of local and informal farmers' knowledge that is often pushed back in processes of agricultural intensification. Although hierarchies and conflicting knowledge can hinder sustainable development processes, they conclude that integrating diverse types of knowledge as well as numerous ways of learning is "a key aspect in surviving, adapting, developing and prospering in modern agriculture" [92] (p. 239). Acknowledging farmers' knowledge as well as networks and movements they engage in is deemed necessary for a transition to agroecology and transformation of the paradigm currently dominating the debate around agriculture [93]. Moreover, the question how to consider and implement scientific knowledge in practice is important and a multitude of factors is decisive whether this is successful: in order to be applied, non-scientific actors have to recognise its value [94]. Knowledge governance that brings together farmers, science, public actors, and private corporations in a balanced power structure may support the co-production, diversification, and acquisition of knowledge and, thus, the application of sustainable agricultural practices [95]. Furthermore, knowledge itself might not be sufficient to enhance sustainable environmental behaviour that also depends on people's environmental emotions such as "environmental values, beliefs, norms, perceptions and motivation" [96] (p. 145). Hubeau et al. [97] consider transdisciplinary initiatives in the agri-food sector being characterised by mutual collaboration, knowledge production, and learning between scientific and societal actors to bear potential to contribute to sustainability transformations.

\subsection{Concrete Approaches to Reduce the Environmental Impact of Agricultural Practices and Support a Sustainability Transition in Agriculture}

In order to account and quantify adverse impacts of agricultural systems on the environment, several studies use life cycle assessment partly combined with other approaches as a method [98-100]. A strength of LCA is considered to be its holistic view [100]. Galán-Martín et al. [99] combine ideas of LCA and the water footprint in a tool to determine best outcomes of food availability and low environmental effects especially of water usage and apply this to the case of wheat production in Spain. Cong and Termansen [98] use a combination of LCA and cost-benefit analysis to assess impacts of pig feed production in both environmental and economic terms. Notarnicola et al. [101] outline the need to further develop LCA methodology and an integrated account of environmental impacts. Bos et al. [102] present another way to assess whether agriculture is sustainable, the "rural sustainability index" including environmental, social, and economic perspectives.

Concrete approaches to reduce adverse impacts of agricultural practices presented in the literature can be clustered according to their foci. The widespread use of pesticides and synthesised inorganic fertilisers contributes to a large extent to negative impacts of agricultural practices on the environment, and may even lead to dangerous consequences for humans as shown in an example of pesticide lock-in structures in Peru [103]. 
Wang et al. [104] find in a case of rice farming that avoiding pesticide overuse is a matter of experience rather than education or awareness. Much research is undertaken how transitions to a more sustainable use of pesticides and fertilisers such as phosphorus may happen (cf. [64,105,106]. Empirical results from a survey of farmers who are at different stages in the transition to sustainable agriculture by changing their use of pesticides and chemical fertilisers in the USA in the 1990s shows that the majority of them did not state negative consequences for yields and profits [107]. It is concluded that education programs on sustainable agriculture with equal standings between farmers and other actors could further foster this transition [107] (p. 154).

Another approach are innovations, mainly technological ones, towards sustainability. While the role of targeted technologies in a transition to sustainable agriculture is questioned by Christianson and Tyndall [108], El Bilali [109] concludes that, rather than scrutinising innovations completely, thinking about appropriate types of innovation to support transitions is key. Thereby, the use of information and communication technologies (ICTs) can have positive environmental consequences through more efficient resource use and input, a reduced ecological footprint, as well as less greenhouse gas emissions and food waste [110]. However, the desired state of a sustainable agro-food system should be defined first, followed by assessing the role ICTs can play to this end to avoid the risks the use of ICTs bears, such as "to increase the power of globalization, which can lead to uniformity of food systems worldwide" [110] (p. 461). Technological innovation systems might be blocked by different structural factors: in the case of water harvesting in Jordan, these were a lack of finance, no common idea about the desired state of the system, and institutional issues that obstruct the innovation's legitimacy [111]. Barriers to technological innovations, e.g., in climate-smart agriculture, can be found both on the sides of supply and demand in various European countries [22]. In the Netherlands, experimental practice projects embedded in the scientific innovation programme "TransForum" try to overcome issues in the agricultural system by applying various innovation strategies [112]. Wigboldus et al. [20] indicate the importance of anticipative scaling processes of innovations in order to correspond to the complexity of agricultural systems.

Issues of water availability are addressed focusing on irrigation in regions with water scarcity by using retreated effluents [27], supplemental irrigation, and adapting sowing practices to rainfall patterns [113].

Agroecology is widely discussed featuring various (bottom-up) examples of agroecological approaches and developments (cf. [59,114,115]). Wezel et al. [24] illustrate agroecology territories as a differently scaled approach in the transition to sustainable agriculture. They formulate three areas which are besides stakeholder support key for a transition, namely, "adaptation of agricultural practices; conservation of biodiversity and natural re-sources; and development of food systems embedded in territories" [24] (p. 135). To strengthen agroecology, policies, education, and public funding for research in favour of agroecology are deemed important $[75,76,116]$. In a review of empirical studies, PalomoCampesino et al. [117] find agroecological practices to enhance ecosystem services in the majority of cases. This is in line with Onaindia et al. [118] (p. 658), who argue that replacing forest plantations monocultures with "a multi-functional landscape, including grasslands and crops, would reinforce food security and enhance biodiversity and relevant ES [ecosystem services]". The potential of effective and sustainable agricultural practices for rural livelihoods is shown in a study in Yangou watershed, China [29]. Analysing changes in land use practices supported by rural development policies, the authors observed a substantial improvement of rural livelihoods and the environment that plays a key part in sustainable rural development and might encourage local governments to pursue such transformative programmes in other parts of the region [29].

\subsection{Urbanisation, Urban Agriculture, and Local Food Networks}

Urbanisation processes can have adverse impacts on agricultural landscapes endangering sustainability, as shown by Su et al. [119] in their case study of Hang-Jia Hu region 
in China. On the other hand, urban agriculture has become a global movement that aims at bridging the divide between rural and urban areas and advocates for (peri-)urban food systems including various stages from food production to consumption within these regions [120] (pp. 342-343). Twenty-five years ago, Van Bers and Robinson [32] emphasised the potential of growing crops in urban areas to contribute to domestic food supply. Hirsch et al. [120] (p. 355) emphasise the niche's character of "searching and testing for new ways in urban food systems, real experimenting, revaluation of the urban-rural relationship around the regional and local urban food provisioning system".

Alternative agricultural practices can also play a key role in the sustainability transformation of cities themselves [52,120-123]. Moschitz et al. [121] synthesise results from a conference on urban agriculture, emphasising its potential to interlock urban and rural areas and to combine alternative forms of food production with different forms of societal engagement and social innovations such as the development of new cooperative models. In order to secure long-term existence and attractiveness of these ideas, economic viability is deemed key [121]. Whether urban agriculture bears potential for sustainability transitions in shrinking cities is to be further investigated [124]. An agroecological approach that aims at transforming vacant land that results from shrinking processes to green infrastructures is seen to bear great potential for the provision of various ecosystem services [122]. Furthermore, local or alternative food networks with their variety of sharing economy models [123] can contribute to governing the transition of urban food systems and initiate social innovation [52].

\subsection{The Role of the Agri-Food Business}

Agri-food firms operate at various stages and levels of a globalised agribusiness. They can influence agricultural patterns: Windhorst [18] (pp. 248-249) expects that "the formation of vertically integrated agribusiness companies" that led to larger, more industrialised and spatially concentrated pig production in the United States and some European countries "may prove to be unsustainable in the long-term". The current state of sustainability initiatives within and among agri-food firms has been assessed in various analyses: the Sustainable Agriculture Initiative launched by three big private players in the food industry includes many other companies today and aims at greening the mainstream production and is considered to bear great potential to this end [125]. Sustainability initiatives pursued by agri-food firms in the United States often seem to lack a clear structure and link to the firm's business strategy [126]. Langendahl et al. [127] (p. 120) conceptualise transitions towards more sustainability in firms in the agri-food sector as "sustainable innovation journeys", emphasising how they engage in sustainability issues in a dynamic way with continuously changing foci and practices as the circumstances and constituting elements of a firm are changing. Rival ideologies among firms building on multiple ways to create legitimacy can be obstacles for firms not to modify their strategic orientation to be more sustainable, notwithstanding existing financial incentives to transition as shown against the background of commodity agriculture [128].

\subsection{The Role of Gender}

Several papers integrate gender issues into the research on agricultural sustainability transformations. In the context of the United States and Australia, they engage with how men and women perceive differently their roles and life in family farms [129], and how constructions of masculinity are changing (cf. [130,131]). While the perception of "monologic" or "conventional masculinity" adheres to a division of labour based on gender, a more reflective and open "dialogic masculinity" questions implications of the former and might be conducive to sustainable farming practices due to different attitudes towards the socio-economic and ecological environment [131] (p. 216). Based on this, factors fostering the latter might be structural changes in rural areas with an emphasis on the environment and women with a job beyond the farm [130]. In a study of six family farms in Minnesota that are transitioning or have transitioned to sustainable agriculture, Meares [129] finds 
that the sustainable agriculture movement predominantly reflects male perspectives as these are the main participants due to the common division of labour between males and females determined by gender. Leslie [132] analyses queer farmers' experiences with heterosexism in the field of sustainable agriculture in New England, United States, which might restrict them in their farming business and argues that overcoming the anchored notion of heteronormativity is key for the participation of queer people in the transition towards sustainable agriculture. A case study of family farms in Spain concludes that because of the close link between production and societal structures in the case of family farms, social aspects might foster sustainability and the integration of the three dimensions of sustainable development [133].

How anchored traditional and cultural patterns influence the use of natural resources is shown in an Ethiopian example: despite the potential of the forest to contribute to food security, its "potential as a food source has been forgotten, a process reinforced by the gendered division of territory and labor responsibilities" and the importance of thriving agricultural production as a determinant of social position in the community [134] (p. 261).

\section{Discussion}

Overall, our review shows that the growing literature on sustainability transitions in agriculture is highly diverse, representing manifold approaches, research fields, geographical areas, and case studies and even reaches out to aspects such as energy efficiency in agroecosystems [37], transitions towards a bioeconomy [135,136], ethical reflections on the legitimisation of precarious working conditions in agriculture by actors in alternative food networks [137], and a comparison of sharing economy models in alternative food networks [124]. This diversity is a stark difference with, for example, the field of sustainable energy transitions, which is a lot more homogenous in terms of referring to a core literature on socio-technical (energy) transitions. In fact, this diversity makes it rather difficult to identify overarching patterns of how transformation in agriculture is characterised. However, most studies seem to have a common starting point, namely negative environmental and social impacts caused but also faced by the current agricultural systems in an era of global change. Considering and safeguarding ecological and social factors seems to be at the core of sustainable agriculture (cf. [64]). Theoretical perspectives on transitions serve as background for a limited share of publications on transitions in agriculture, and they are often combined to new frameworks or methods for analysis. It appears that the dominant perspective on agricultural transitions is one of (local) niche developments seeking "upscaling".

The analysed literature focuses on various subfields in agriculture and there is potential for change at various elements targeted by those approaches. The identified thematic clusters show the multitude of dimensions fostering or impeding agricultural transformations and their connection and embeddedness within wider societal contexts. Concrete leverage points for governing agricultural transitions towards sustainability include public funding of sustainable agriculture, reforming counterproductive incentive systems such as the EU Common Agricultural Policy; fostering institutions for knowledge exchange and learning as well as knowledge co-production; collaborative governance mechanisms; educational programs on sustainable agriculture; rural development policies as well as local or alternative food governance networks. Private governance through agri-food business has not yet proved to be a game changer-but neither has any of the other initiatives.

It needs to be stressed that, even though the field is quickly growing, the amount of literature available on the topic, and that considered in this review, is limited. General conclusions drawn e.g., of influences on regime change are no more than tentative based on an explorative approach to reviewing literature in an emerging research field. While not only different topics arise, Weber et al. [17] identify various research lenses approaching the topic of food system transformations, with sustainable agriculture only being one of them. A holistic sustainability transition of agricultural systems might only be possible if the different dimensions identified in this review are combined and interact. Still, it remains 
rather open how this could happen. Linkages to global sustainability agendas such as the SDGs appear seldom in the agricultural transitions literature but show significant increase in publications within the last few years (cf. [134,138]). Still, a variety of local case studies shows potential for small-scale changes that might be transferable also to other regions. Given the enormous challenges of governing agricultural systems to sustainability on multiple geographical levels, it appears that more integrative, comparative work and perhaps more coherence in conceptual approaches would greatly benefit the field, which is currently highly fragmented.

Author Contributions: I.C.M. conceptualised, performed the analysis, and contributed substantially to the writing of the manuscript. J.N. conceptualised the analysis and discussed its results, and contributed to the writing of the manuscript. All authors have read and agreed to the published version of the manuscript.

Funding: This research received no external funding.

Conflicts of Interest: The authors declare no conflict of interest.

\section{Appendix A. List of 153 Articles Considered in the Review}

1. Ahmed, F.; Al-Amin, A. Q.; Masud, M. M.; Kari, F.; Mohamad, Z. A science framework (SF) for agricultural sustainability. Anais da Academia Brasileira de Ciencias 2015, 87, 1887-1902, doi: 10.1590/0001-3765201520130368.

2. Ahmed, S.; Sclafani, A.; Aquino, E.; Kala, S.; Barias, L.; Eeg, J. Building student capacity to lead sustainability transitions in the food system through farm-based authentic research modules in sustainability sciences (FARMS). Elementa 2017, 5, 46, doi: $10.1525 /$ elementa.239.

3. Allaire, F.; Stinner, B.; Stinner, D.; Hartzler, J.; Moore, R.; Hoy, C.; Dorsey, J.; Hitzhusen, F.; Weaver, M. Learning sustainable development with a farm enterprise and its community. Journal of Sustainable Agriculture 2001, 19, 65-83, doi: 10.1300/J064v19n01_06.

4. Audet, R.; Lefèvre, S.; Brisebois, É.; El-Jed, M. Structuring tensions and key relations of montreal seasonal food markets in the sustainability transition of the agri-food sector. Sustainability (Switzerland) 2017, 9, 320, doi: 10.3390/su9030320.

5. Bennich, T.; Belyazid, S.; Kopainsky, B.; Diemer, A. Understanding the transition to a bio-based economy: Exploring dynamics linked to the agricultural sector in Sweden. Sustainability (Switzerland) 2018, 10, 1504, doi: 10.3390/su10051504.

6. Blesh, J.; Wolf, S. A. Transitions to agroecological farming systems in the Mississippi River Basin: toward an integrated socioecological analysis. Agriculture and Human Values 2014, 31, 621-635, doi: 10.1007/s10460-014-9517-3.

7. Boddey, R. M.; Xavier, D. F.; Alves, B. J. R.; Urquiaga, S. Brazilian Agriculture: The Transition to Sustainability. Journal of Crop Production 2003, 9, 593-621, doi: 10.1300/J144v09n01_10.

8. Bos, M. G.; van den Bosch, H.; Diemont, H.; Keulen, H.; Lahr, J.; Meijerink, G.; Verhagen, A. Quantifying the sustainability of agriculture. Irrigation and Drainage Systems 2007, 21, 1-15, doi: 10.1007/s10795-006-9014-y.

9. Bosma, R.; Sidik, A. S.; van Zwieten, P.; Aditya, A.; Visser, L. Challenges of a transition to a sustainably managed shrimp culture agro-ecosystem in the Mahakam delta, East Kalimantan, Indonesia. Wetlands Ecology and Management 2012, 20, 89-99, doi: 10.1007/s11273-011-9244-0.

10. Bui, S.; Cardona, A.; Lamine, C.; Cerf, M. Sustainability transitions: Insights on processes of niche-regime interaction and regime reconfiguration in agri-food systems. Journal of Rural Studies 2016, 48, 92-103, doi: 10.1016/j.jrurstud.2016.10.003.

11. Calleros-Islas, A. Sustainability assessment. An adaptive low-input tool applied to the management of agroecosystems in México. Ecological Indicators 2019, 105, 386-397, doi: 10.1016/j.ecolind.2017.12.040.

12. Chantre, E.; Cardona, A. Trajectories of French Field Crop Farmers Moving Toward Sustainable Farming Practices: Change, Learning, and Links with the Advisory Ser- 
vices. Agroecology and Sustainable Food Systems 2014, 38, 573-602, doi: $10.1080 / 21683565.2013 .876483$.

13. Christianson, L.; Tyndall, J. Seeking a dialogue: A targeted technology for sustainable agricultural systems in the American Corn Belt. Sustainability: Science, Practice, and Policy 2011, 7, 70-77, doi: 10.1080/15487733.2011.11908075.

14. Cobb, D.; Dolman, P.; O'Riordan, T. Interpretations of sustainable agriculture in the UK. Progress in Human Geography 1999, 23, 209-235.

15. Coldwell, I. New farming masculinities: 'More than just shit-kickers', we're 'switchedon' farmers wanting to 'balance lifestyle, sustainability and coin'. Journal of Sociology 2007, 43, 87-103, doi: 10.1177/1440783307073936.

16. Cong, R. G.; Termansen, M. A bio-economic analysis of a sustainable agricultural transition using green biorefinery. Science of the Total Environment 2016, 571, 153-163, doi: 10.1016/j.scitotenv.2016.07.137.

17. Coquil, X.; Cerf, M.; Auricoste, C.; Joannon, A.; Barcellini, F.; Cayre, P.; Chizallet, M.; Dedieu, B.; Hostiou, N.; Hellec, F.; Lusson, J. M.; Olry, P.; Omon, B.; Prost, L. Questioning the work of farmers, advisors, teachers and researchers in agroecological transition. A review. Agronomy for Sustainable Development 2018, 38, 47, doi: 10.1007/s13593-018-0524-4.

18. Coquil, X.; Dedieu, B.; Béguin, P. Professional transitions towards sustainable farming systems: The development of farmers' professional worlds. Work 2017, 57, 325-337, doi: $10.3233 /$ WOR-172565.

19. Crivits, M.; de Krom, M. P. M. M.; Block, T.; Dessein, J. Using policy discourses to open up the conceptual space of farm education: inspiration from a Belgian farm education network. Environmental Education Research 2018, 24, 1320-1339, doi: 10.1080/13504622.2017.1301384.

20. Cross, R.; Ampt, P. Exploring Agroecological Sustainability: Unearthing Innovators and Documenting a Community of Practice in Southeast Australia. Society and Natural Resources 2017, 30, 585-600, doi: 10.1080/08941920.2016.1230915.

21. Dai, Z. Intensive agropastoralism: Dryland degradation, the Grain-to-Green Program and islands of sustainability in the Mu Us Sandy Land of China. Agriculture, Ecosystems and Environment 2010, 138, 249-256, doi: 10.1016/j.agee.2010.05.006.

22. Davidson, D. J.; Jones, K. E.; Parkins, J. R. Food safety risks, disruptive events and alternative beef production: a case study of agricultural transition in Alberta. Agriculture and Human Values 2016, 33, 359-371, doi: 10.1007/s10460-015-9609-8.

23. Daviron, B.; Vagneron, I. From commoditisation to de-commoditisation ... and back again: Discussing the role of sustainability standards for agricultural products. Development Policy Review 2011, 29, 91-113, doi: 10.1111/j.1467-7679.2011.00515.x.

24. Delbaere, B.; Mikos, V.; Pulleman, M. European Policy Review: Functional agrobiodiversity supporting sustainable agriculture. Journal for Nature Conservation 2014, 22, 193-194, doi: 10.1016/j.jnc.2014.01.003.

25. DeLonge, M. S.; Miles, A.; Carlisle, L. Investing in the transition to sustainable agriculture. Environmental Science and Policy 2016, 55, 266-273, doi: 10.1016/j.envsci.2015.09.013.

26. Dentoni, D.; Waddell, S.; Waddock, S. Pathways of transformation in global food and agricultural systems: implications from a large systems change theory perspective. Current Opinion in Environmental Sustainability 2017, 29, 8-13, doi: 10.1016/j.cosust.2017.10.003.

27. Dodd, M. B.; Wedderburn, M. E.; Parminter, T. G.; Thorrold, B. S.; Quinn, J. M. Transformation toward agricultural sustainability in New Zealand hill country pastoral landscapes. Agricultural Systems 2008, 98, 95-107, doi: 10.1016/j.agsy.2008.04.004.

28. Doremus, H.; Dan Tarlock, A. Fish, Farms, and the Clash of Cultures in the Klamath Basin. Ecology Law Quarterly 2003, 30, 279-350.

29. Dwyer, J. Transformation for sustainable agriculture: What role for the second pillar of CAP? Bio-based and Applied Economics 2013, 2, $29-47$. 
30. Eksvärd, K. Facilitating Systemic Research and Learning and the transition to agricultural sustainability. Journal of Agricultural Education and Extension 2010, 16, 265-280, doi: 10.1080/1389224X.2010.502759.

31. Eksvärd, K.; Rydberg, T. Integrating Participatory Learning and Action Research and Systems Ecology: A Potential for Sustainable Agriculture Transitions. Systemic Practice and Action Research 2010, 23, 467-486, doi: 10.1007/s11213-010-9172-6.

32. El Bilali, H. Relation between innovation and sustainability in the agro-food system. Italian Journal of Food Science 2018, 30, 200-225, doi: 10.14674/IJFS-1096.

33. El Bilali, H. Transition heuristic frameworks in research on agro-food sustainability transitions. Environment, Development and Sustainability 2020, 22, 1693-1728, doi: $10.1007 /$ s10668-018-0290-0.

34. El Bilali, H.; Allahyari, M. S. Transition towards sustainability in agriculture and food systems: Role of information and communication technologies. Information Processing in Agriculture 2018, 5, 456-464, doi: 10.1016/j.inpa.2018.06.006.

35. Epps, R. The sustainability of australian agricultural production systems: A realistic objective or simply a desirable aim? Australian Geographer 1995, 26, 173-179, doi: 10.1080/00049189508703147.

36. Feola, G.; Binder, C. R. Towards an improved understanding of farmers' behaviour: The integrative agent-centred (IAC) framework. Ecological Economics 2010, 69, 2323 2333, doi: 10.1016/j.ecolecon.2010.07.023.

37. Fernandez, M.; Williams, J.; Figueroa, G.; Graddy-Lovelace, G.; MacHado, M.; Vazquez, L.; Perez, N.; Casimiro, L.; Romero, G.; Funes-Aguilar, F. New opportunities, new challenges: Harnessing Cuba's advances in agroecology and sustainable agriculture in the context of changing relations with the United States. Elementa 2018, 6, 76, doi: 10.1525/elementa.337.

38. Foster, K.; Neufeldt, H. Biocarbon projects in agroforestry: Lessons from the past for future development. Current Opinion in Environmental Sustainability 2014, 6, 148-154, doi: 10.1016/j.cosust.2013.12.002.

39. Furman, C.; Roncoli, C.; Nelson, D. R.; Hoogenboom, G. Growing food, growing a movement: Climate adaptation and civic agriculture in the Southeastern United States. Agriculture and Human Values 2014, 31, 69-82, doi: 10.1007/s10460-013-9458-2.

40. Galán-Martín, Á.; Vaskan, P.; Antón, A.; Esteller, L. J.; Guillén-Gosálbez, G. Multiobjective optimization of rainfed and irrigated agricultural areas considering production and environmental criteria: a case study of wheat production in Spain. Journal of Cleaner Production 2017, 140, 816-830, doi: 10.1016/j.jclepro.2016.06.099.

41. Galdeano-Gómez, E.; Pérez-Mesa, J. C.; Godoy-Durán, Á. The social dimension as a driver of sustainable development: the case of family farms in southeast Spain. Sustainability Science 2016, 11, 349-362, doi: 10.1007/s11625-015-0318-4.

42. Gaudino, S.; Reidsma, P.; Kanellopoulos, A.; Sacco, D.; van Ittersum, M. K. Integrated assessment of the EU's greening reform and feed self-sufficiency scenarios on dairy farms in Piemonte, Italy. Agriculture (Switzerland) 2018, 8, 137, doi: 10.3390/agriculture8090137.

43. Gingrich, S.; Marco, I.; Aguilera, E.; Padró, R.; Cattaneo, C.; Cunfer, G.; Guzmán, G. I.; MacFadyen, J.; Watson, A. Agroecosystem energy transitions in the old and new worlds: trajectories and determinants at the regional scale. Regional Environmental Change 2018, 18, 1089-1101, doi: 10.1007/s10113-017-1261-y. 
44. Goglio, P.; Smith, W. N.; Worth, D. E.; Grant, B. B.; Desjardins, R. L.; Chen, W.; Tenuta, M.; McConkey, B. G.; Williams, A.; Burgess, P. Development of Crop.LCA, an adaptable screening life cycle assessment tool for agricultural systems: A Canadian scenario assessment. Journal of Cleaner Production 2018, 172, 3770-3780, doi: 10.1016/j.jclepro.2017.06.175.

45. Gómez, L. F.; Ríos-Osorio, L.; Eschenhagen, M. L. Agroecology publications and coloniality of knowledge. Agronomy for Sustainable Development 2013, 33, 355-362, doi: $10.1007 /$ s13593-012-0109-6.

46. Grin, J. The politics of transition governance in Dutch agriculture. Conceptual understanding and implications for transition management. International Journal of Sustainable Development 2012, 15, 72-89, doi: 10.1504/IJSD.2012.044035.

47. Grossman, J. J. Ecosystem service trade-offs and land use among smallholder farmers in Eastern Paraguay. Ecology and Society 2015, 20, 19, doi: 10.5751/ES-06953-200119.

48. Guthman, J. Thinking inside the neoliberal box: The micro-politics of agro-food philanthropy. Geoforum 2008, 39, 1241-1253, doi: 10.1016/j.geoforum.2006.09.001.

49. Hagedorn, K. Post-socialist farmers' cooperatives in central and Eastern Europe. Annals of Public and Cooperative Economics 2014, 85, 555-577, doi: 10.1111/apce.12051.

50. Hammond Wagner, C.; Cox, M.; Bazo Robles, J. L. Pesticide lock-in in small scale Peruvian agriculture. Ecological Economics 2016, 129, 72-81, doi: 10.1016/j.ecolecon.2016.05.013.

51. Hanson, J. C.; Kauffman, C. S.; Schauer, A. Attitudes and Practices of Sustainable Farmers, with Applications to Designing a Sustainable Agriculture Extension Program. Journal of Sustainable Agriculture 1996, 6, 135-156, doi: 10.1300/J064v06n02_12.

52. Herrmann, D. L.; Chuang, W. C.; Schwarz, K.; Bowles, T. M.; Garmestani, A. S.; Shuster, W. D.; Eason, T.; Hopton, M. E.; Allen, C. R. Agroecology for the shrinking city. Sustainability (Switzerland) 2018, 10, 675, doi: 10.3390/su10030675.

53. Hill, S. B.; MacRae, R. J. Organic farming in Canada. Agriculture, Ecosystems and Environment 1992, 39, 71-84, doi: 10.1016/0167-8809(92)90205-P.

54. Hill, S. B.; MacRae, R. J. Conceptual Framework for the Transition from Conventional to Sustainable Agriculture. Journal of Sustainable Agriculture 1996, 7, 81-87, doi: 10.1300/J064v07n01_07.

55. Hirsch, D.; Meyer, C. H.; Klement, J.; Hamer, M.; Terlau, W. Urban agriculture and food systems dynamics in the German Bonn/Rhein-Sieg Region. International Journal on Food System Dynamics 2016, 7, 341-359, doi: 10.18461/ijfsd.v7i4.745.

56. Honig, M.; Petersen, S.; Shearing, C.; Pintér, L.; Kotze, I. The conditions under which farmers are likely to adapt their behaviour: A case study of private land conservation in the Cape Winelands, South Africa. Land Use Policy 2015, 48, 389-400, doi: 10.1016/j.landusepol.2015.06.016.

57. Hubeau, M.; Marchand, F.; Coteur, I.; Debruyne, L.; Van Huylenbroeck, G. A reflexive assessment of a regional initiative in the agri-food system to test whether and how it meets the premises of transdisciplinary research. Sustainability Science 2018, 13, 11371154, doi: $10.1007 /$ s11625-017-0514-5.

58. Hubeau, M.; Marchand, F.; Coteur, I.; Mondelaers, K.; Debruyne, L.; Van Huylenbroeck, G. A new agri-food systems sustainability approach to identify shared transformation pathways towards sustainability. Ecological Economics 2017, 131, 52-63, doi: 10.1016/j.ecolecon.2016.08.019.

59. Hubeau, M.; Marchand, F.; Van Huylenbroeck, G. Sustainability experiments in the agri-food system: Uncovering the factors of new governance and collaboration success. Sustainability (Switzerland) 2017, 9, 1027, doi: 10.3390/su9061027.

60. Huttunen, S.; Oosterveer, P. Transition to Sustainable Fertilisation in Agriculture, A Practices Approach. Sociologia Ruralis 2017, 57, 191-210, doi: 10.1111/soru.12118.

61. Ingram, J. Agronomist-farmer knowledge encounters: An analysis of knowledge exchange in the context of best management practices in England. Agriculture and Human Values 2008, 25, 405-418, doi: 10.1007/s10460-008-9134-0. 
62. Ingram, J.; Maye, D.; Kirwan, J.; Curry, N.; Kubinakova, K. Interactions between Niche and Regime: An Analysis of Learning and Innovation Networks for Sustainable Agriculture across Europe. Journal of Agricultural Education and Extension 2015, 21, 5571, doi: 10.1080/1389224X.2014.991114.

63. Ingram, J.; Morris, C. The knowledge challenge within the transition towards sustainable soil management: An analysis of agricultural advisors in England. Land Use Policy 2007, 24, 100-117, doi: 10.1016/j.landusepol.2005.07.002.

64. Isgren, E.; Ness, B. Agroecology to promote just sustainability transitions: Analysis of a civil society network in the Rwenzori region, western Uganda. Sustainability (Switzerland) 2017, 9, 1357, doi: 10.3390/su9081357.

65. Jacobi, J.; Llanque, A. "When we stand up, they have to negotiate with Us": Power relations in and between an agroindustrial and an indigenous food system in Bolivia. Sustainability (Switzerland) 2018, 10, 4001, doi: 10.3390/su10114001.

66. Janousek, A.; Markey, S.; Roseland, M. "We see a real opportunity around food waste": exploring the relationship between on-farm food waste and farm characteristics. Agroecology and Sustainable Food Systems 2018, 42, 933-960, doi: 10.1080/21683565.2018.1468381.

67. Järnberg, L.; Enfors Kautsky, E.; Dagerskog, L.; Olsson, P. Green niche actors navigating an opaque opportunity context: Prospects for a sustainable transformation of Ethiopian agriculture. Land Use Policy 2018, 71, 409-421, doi: 10.1016/j.landusepol.2017.11.053.

68. Joffre, O. M.; Klerkx, L.; Khoa, T. N. D. Aquaculture innovation system analysis of transition to sustainable intensification in shrimp farming. Agronomy for Sustainable Development 2018, 38, 34, doi: 10.1007/s13593-018-0511-9.

69. Kanchanaroek, Y.; Aslam, U. Policy schemes for the transition to sustainable agricultureFarmer preferences and spatial heterogeneity in northern Thailand. Land Use Policy 2018, 78, 227-235, doi: 10.1016/j.landusepol.2018.05.026.

70. Karpouzoglou, T.; Barron, J. A global and regional perspective of rainwater harvesting in sub-Saharan Africa's rainfed farming systems. Physics and Chemistry of the Earth 2014, 72, 43-53, doi: 10.1016/j.pce.2014.09.009.

71. Konefal, J. Governing sustainability transitions: Multi-stakeholder initiatives and regime change in United States agriculture. Sustainability (Switzerland) 2015, 7, 612633, doi: 10.3390/su7010612.

72. Koppel, B.; Zurick, D. Rural transformation and the future of agricultural development policy in Asia. Agricultural Administration and Extension 1988, 28, 283-301, doi: 10.1016/0269-7475(88)90003-7.

73. Kumar, V.; Mills, D. J.; Anderson, J. D.; Mattoo, A. K. An alternative agriculture system is defined by a distinct expression profile of select gene transcripts and proteins. Proceedings of the National Academy of Sciences of the United States of America 2004, 101, 10535-10540, doi: 10.1073/pnas.0403496101.

74. Lamine, C.; Garçon, L.; Brunori, G. Territorial agrifood systems: A Franco-Italian contribution to the debates over alternative food networks in rural areas. Journal of Rural Studies 2019, 68, 159-170, doi: 10.1016/j.jrurstud.2018.11.007.

75. Langendahl, P. A.; Cook, M.; Potter, S. Sustainable innovation journeys: exploring the dynamics of firm practices as part of transitions to more sustainable food and farming. Local Environment 2016, 21, 105-123, doi: 10.1080/13549839.2014.926869.

76. Leslie, I. S. Queer Farmers: Sexuality and the Transition to Sustainable Agriculture. Rural Sociology 2017, 82, 747-771, doi: 10.1111/ruso.12153.

77. Leveau, L.; Soulignac, V. Knowledge management for sustainable agro-systems: Can analysis tools help us to understand and support agricultural communities of practice? Case of the French lentil production. International Journal on Food System Dynamics 2018, 9, 197-206, doi: 10.18461/ijfsd.v9i2.927.

78. Long, T. B.; Blok, V.; Coninx, I. Barriers to the adoption and diffusion of technological innovations for climate-smart agriculture in Europe: Evidence from the Netherlands, France, Switzerland and Italy. Journal of Cleaner Production 2016, 112, 9-21, doi: 10.1016/j.jclepro.2015.06.044. 
79. Lu, Y. C.; Kelly, T. C. Implications of sustainable agriculture for the world food situation. Food Reviews International 1995, 11, 255-280, doi: 10.1080/87559129509541042.

80. Macrae, R. J.; Hill, S. B.; Henning, J.; Bentley, A. J. Policies, programs, and regulations to support the transition to sustainable agriculture in Canada. American Journal of Alternative Agriculture 1990, 5, 76-92, doi: 10.1017/S0889189300003325.

81. Manuel-Navarrete, D.; Gallopín, G. C. Feeding the world sustainably: Knowledge governance and sustainable agriculture in the Argentine Pampas. Environment, Development and Sustainability 2012, 14, 321-333, doi: 10.1007/s10668-011-9326-4.

82. Marquardt, K.; Vico, G.; Glynn, C.; Weih, M.; Eksvärd, K.; Dalin, P.; Björkman, C. Farmer perspectives on introducing perennial cereal in Swedish farming systems: a sustainability analysis of plant traits, farm management, and ecological implications. Agroecology and Sustainable Food Systems 2016, 40, 432-450, doi: 10.1080/21683565.2016.1141146.

83. Martin, E.; Fahey, B. The interorganizational challenge of agricultural reform in Bosnia and Herzegovina. South East European Journal of Economics and Business 2009, 4, 7-22, doi: 10.2478/v10033-009-0010-7.

84. Martin, G.; Allain, S.; Bergez, J. E.; Burger-Leenhardt, D.; Constantin, J.; Duru, M.; Hazard, L.; Lacombe, C.; Magda, D.; Magne, M. A.; Ryschawy, J.; Thénard, V.; Tribouillois, H.; Willaume, M. How to address the sustainability transition of farming systems? A conceptual framework to organize research. Sustainability (Switzerland) 2018, 10, 2083, doi: 10.3390/su10062083.

85. Massicotte, M. J.; Kelly-Bisson, C. What's wrong with permaculture design courses? Brazilian lessons for agroecological movement-building in Canada. Agriculture and Human Values 2019, 36, 581-594, doi: 10.1007/s10460-018-9870-8.

86. Meares, A. C. Making the transition from conventional to sustainable agriculture: Gender, social movement participation, and quality of life on the family farm. Rural Sociology 1997, 62, 21-47, doi.

87. Meek, D. The cultural politics of the agroecological transition. Agriculture and Human Values 2016, 33, 275-290, doi: 10.1007/s10460-015-9605-z.

88. Meynard, J. M.; Jeuffroy, M. H.; Le Bail, M.; Lefèvre, A.; Magrini, M. B.; Michon, C. Designing coupled innovations for the sustainability transition of agrifood systems. Agricultural Systems 2017, 157, 330-339, doi: 10.1016/j.agsy.2016.08.002.

89. Migliorini, P.; Gkisakis, V.; Gonzalvez, V.; Raigón, M. D.; Bàrberi, P. Agroecology in mediterranean Europe: Genesis, state and perspectives. Sustainability (Switzerland) 2018, 10, 2724, doi: 10.3390/su10082724.

90. Miles, A.; DeLonge, M. S.; Carlisle, L. Triggering a positive research and policy feedback cycle to support a transition to agroecology and sustainable food systems. Agroecology and Sustainable Food Systems 2017, 41, 855-879, doi: 10.1080/21683565.2017.1331179.

91. Miralles, I.; Dentoni, D.; Pascucci, S. Understanding the organization of sharing economy in agri-food systems: evidence from alternative food networks in Valencia. Agriculture and Human Values 2017, 34, 833-854, doi: 10.1007/s10460-017-9778-8.

92. Moschitz, H.; Moser, R.; Di Giulio, M. Urban agriculture: Stimulus for a sustainable transformation of city and countryside. GAIA 2017, 26, 65-67, doi: 10.14512/gaia.26.1.16.

93. Nair, C. M.; Salin, K. R. Current status and prospects of farming the giant river prawn Macrobrachium rosenbergii (De Man) and the monsoon river prawn Macrobrachium malcolmsonii (H.M. Edwards) in India. Aquaculture Research 2012, 43, 999-1014, doi: 10.1111/j.1365-2109.2011.03074.x.

94. Nischalke, S. M.; Abebe, M.; Wondimagegnhu, B. A.; Kriesemer, S. K.; Beuchelt, T. Forgotten Forests? Food Potential of Ancient Coffee Forests and Agroforestry Systems in the Southwestern Ethiopian Mountains, Seen Through a Gender Lens. Mountain Research and Development 2017, 37, 254-262, doi: 10.1659/MRD-JOURNAL-D-16-00096.1.

95. Notarnicola, B.; Sala, S.; Anton, A.; McLaren, S. J.; Saouter, E.; Sonesson, U. The role of life cycle assessment in supporting sustainable agri-food systems: A review of the challenges. Journal of Cleaner Production 2017, 140, 399-409, doi: 10.1016/j.jclepro.2016.06.071. 
96. Obayelu, A. E.; Okuneyep, P. A.; Shittu, A. M.; Afolami, C. A.; Dipeolu, A. O. Determinants and the perceived effects of adoption of selected improved food crop technologies by smallholder farmers along the value chain in Nigeria. Journal of Agriculture and Environment for International Development 2016, 110, 155-172, doi: 10.12895/jaeid.20161.436.

97. Oda, K.; Rupprecht, C. D. D.; Tsuchiya, K.; McGreevy, S. R. Urban agriculture as a sustainability transition strategy for shrinking cities? Land use change trajectory as an obstacle in Kyoto city, Japan. Sustainability (Switzerland) 2018, 10, 1048, doi: $10.3390 /$ su10041048.

98. Öhlund, E.; Zurek, K.; Hammer, M. Towards Sustainable Agriculture? The EU framework and local adaptation in Sweden and Poland. Environmental Policy and Governance 2015, 25, 270-287, doi: 10.1002/ eet.1687.

99. Ollivier, G.; Magda, D.; Mazé, A.; Plumecocq, G.; Lamine, C. Agroecological transitions: What can sustainability transition frameworks teach us? an ontological and empirical analysis. Ecology and Society 2018, 23, 5, doi: 10.5751/ES-09952-230205.

100. Onaindia, M.; Peña, L.; de Manuel, B. F.; Rodríguez-Loinaz, G.; Madariaga, I.; PalaciosAgúndez, I.; Ametzaga-Arregi, I. Land use efficiency through analysis of agrological capacity and ecosystem services in an industrialized region (Biscay, Spain). Land Use Policy 2018, 78, 650-661, doi: 10.1016/j.landusepol.2018.06.049.

101. Ortiz, W.; Vilsmaier, U.; Acevedo Osorio, Á. The diffusion of sustainable family farming practices in Colombia: an emerging sociotechnical niche? Sustainability Science 2018, 13, 829-847, doi: 10.1007/s11625-017-0493-6.

102. Pala, M.; Ryan, J.; Mazid, A.; Abdallah, O.; Nachit, M. Wheat farming in Syria: An approach to economic transformation and sustainability. Renewable Agriculture and Food Systems 2004, 19, 30-34, doi: 10.1079/RAFS200056.

103. Palomo-Campesino, S.; González, J. A.; García-Llorente, M. Exploring the connections between agroecological practices and ecosystem services: A systematic literature review. Sustainability (Switzerland) 2018, 10, 4339, doi: 10.3390/su10124339.

104. Pant, L. P. Critical systems of learning and innovation competence for addressing complexity in transformations to agricultural sustainability. Agroecology and Sustainable Food Systems 2014, 38, 336-365, doi: 10.1080/21683565.2013.833157.

105. Pant, L. P.; Kc, K. B.; Fraser, E. D. G.; Shrestha, P. K.; Lama, A. B.; Jirel, S. K.; Chaudhary, P. Adaptive Transition Management for Transformations to Agricultural Sustainability in the Karnali Mountains of Nepal. Agroecology and Sustainable Food Systems 2014, 38, 1156-1183, doi: 10.1080/21683565.2014.942022.

106. Peter, G.; Bell, M. M.; Jarnagin, S.; Bauer, D. Coming Back Across the Fence: Masculinity and the Transition to Sustainable Agriculture. Rural Sociology 2000, 65, 215-233, doi.

107. Peters, C. J.; Picardy, J. A.; Darrouzet-Nardi, A.; Griffin, T. S. Feed conversions, ration compositions, and land use efficiencies of major livestock products in U.S. agricultural systems. Agricultural Systems 2014, 130, 35-43, doi: 10.1016/j.agsy.2014.06.005.

108. Pigford, A. A. E.; Hickey, G. M.; Klerkx, L. Beyond agricultural innovation systems? Exploring an agricultural innovation ecosystems approach for niche design and development in sustainability transitions. Agricultural Systems 2018, 164, 116-121, doi: 10.1016/j.agsy.2018.04.007.

109. Pimbert, M. P.; Moeller, N. I. Absent agroecology aid: On UK agricultural development assistance since 2010. Sustainability (Switzerland) 2018, 10, 505, doi: 10.3390/su10020505.

110. Plumecocq, G.; Debril, T.; Duru, M.; Magrini, M. B.; Sarthou, J. P.; Therond, O. The plurality of values in sustainable agriculture models: Diverse lock-in and coevolution patterns. Ecology and Society 2018, 23, doi: 10.5751/ES-09881-230121.

111. Poetz, K.; Haas, R.; Balzarova, M. Emerging strategic corporate social responsibility partnership initiatives in agribusiness: The case of the sustainable agriculture initiative. Journal on Chain and Network Science 2012, 12, 151-165, doi: 10.3920/JCNS2012.x010. 
112. Ponisio, L. C.; Kremen, C. System-level approach needed to evaluate the transition to more sustainable agriculture. Proceedings of the Royal Society B: Biological Sciences 2016, 283, 20151623, doi: 10.1098/rspb.2015.1623.

113. Press, M.; Arnould, E. J.; Murray, J. B.; Strand, K. Ideological challenges to changing strategic orientation in commodity agriculture. Journal of Marketing 2014, 78, 103-119, doi: $10.1509 /$ jm.13.0280.

114. Pretty, J. N. Sustainable Agriculture, people and the resource base: Impacts on food production. Forum for Development Studies 1997, 24, 7-32, doi: 10.1080/08039410.1997.9666047.

115. Raeisi, A.; Bijani, M.; Chizari, M. The mediating role of environmental emotions in transition from knowledge to sustainable use of groundwater resources in Iran's agriculture. International Soil and Water Conservation Research 2018, 6, 143-152, doi: 10.1016/j.iswcr.2018.01.002.

116. Rasmussen, J.; Kaltoft, P. Alternative versus conventional attitudes in higher agricultural education. Biological Agriculture and Horticulture 2003, 20, 347-363, doi: 10.1080/01448765.2003.9754978.

117. Rendon, O. R.; Dallimer, M.; Paavola, J. Flow and rent-based opportunity costs of water ecosystem service provsion in a complex farming system. Ecology and Society 2016, 21, 36, doi: 10.5751/ES-08787-210436.

118. Rockström, J.; Williams, J.; Daily, G.; Noble, A.; Matthews, N.; Gordon, L.; Wetterstrand, H.; DeClerck, F.; Shah, M.; Steduto, P.; de Fraiture, C.; Hatibu, N.; Unver, O.; Bird, J.; Sibanda, L.; Smith, J. Sustainable intensification of agriculture for human prosperity and global sustainability. Ambio 2017, 46, 4-17, doi: 10.1007/s13280-016-0793-6.

119. Ross, R. B.; Pandey, V.; Ross, K. L. Sustainability and strategy in U.S. agri-food firms: An assessment of current practices. International Food and Agribusiness Management Review 2015, 18, 17-48.

120. Ruttan, V. W. The transition to agricultural sustainability. Proceedings of the National Academy of Sciences of the United States of America 1999, 96, 5960-5967, doi: 10.1073/pnas.96.11.5960.

121. Santhanam-Martin, M.; Ayre, M.; Nettle, R. Community sustainability and agricultural landscape change: insights into the durability and vulnerability of the productivist regime. Sustainability Science 2015, 10, 207-217, doi: 10.1007/s11625-014-0268-2.

122. Sarkar, S. F.; Poon, J. S.; Lepage, E.; Bilecki, L.; Girard, B. Enabling a sustainable and prosperous future through science and innovation in the bioeconomy at Agriculture and Agri-Food Canada. New Biotechnology 2018, 40, 70-75, doi: 10.1016/j.nbt.2017.04.001.

123. Sharma, T.; Carmichael, J.; Klinkenberg, B. A spatially explicit modeling approach to explore scenarios of sustainable agriculture futures. Journal of the Indian Society of Remote Sensing 2005, 33, 353-363, doi: 10.1007/BF02990056.

124. Sharma, T.; Carmichael, J.; Klinkenberg, B. Integrated modeling for exploring sustainable agriculture futures. Futures 2006, 38, 93-113, doi: 10.1016/j.futures.2005.04.006.

125. Sherwood, S.; van Bommel, S.; Paredes, M. Self-organization and the bypass: Reimagining institutions for more sustainable development in agriculture and food. Agriculture (Switzerland) 2016, 6, 1-19, doi: 10.3390/agriculture6040066.

126. Sixt, G. N.; Klerkx, L.; Griffin, T. S. Transitions in water harvesting practices in Jordan's rainfed agricultural systems: Systemic problems and blocking mechanisms in an emerging technological innovation system. Environmental Science and Policy 2018, 84, 235-249, doi: 10.1016/j.envsci.2017.08.010.

127. Southavilay, B.; Nanseki, T.; Takeuchi, S. Analysis on policies and agricultural transition: Challenges in promoting sustainable agriculture in Northern Laos. Journal of the Faculty of Agriculture, Kyushu University 2013, 58, 219-223.

128. Su, S.; Jiang, Z.; Zhang, Q.; Zhang, Y. Transformation of agricultural landscapes under rapid urbanization: A threat to sustainability in Hang-Jia-Hu region, China. Applied Geography 2011, 31, 439-449, doi: 10.1016/j.apgeog.2010.10.008. 
129. Šūmane, S.; Kunda, I.; Knickel, K.; Strauss, A.; Tisenkopfs, T.; Rios, I. D. I.; Rivera, M.; Chebach, T.; Ashkenazy, A. Local and farmers' knowledge matters! How integrating informal and formal knowledge enhances sustainable and resilient agriculture. Journal of Rural Studies 2018, 59, 232-241, doi: 10.1016/j.jrurstud.2017.01.020.

130. Swagemakers, P.; Domínguez García, M. D.; Milone, P.; Ventura, F.; Wiskerke, J. S. C. Exploring cooperative place-based approaches to restorative agriculture. Journal of Rural Studies 2019, 68, 191-199, doi: 10.1016/j.jrurstud.2018.12.003.

131. Tang, Q.; Bennett, S. J.; Xu, Y.; Li, Y. Agricultural practices and sustainable livelihoods: Rural transformation within the Loess Plateau, China. Applied Geography 2013, 41, 1523, doi: 10.1016/j.apgeog.2013.03.007.

132. Teixeira, H. M.; van den Berg, L.; Cardoso, I. M.; Vermue, A. J.; Bianchi, F. J. J. A.; Peña-Claros, M.; Tittonell, P. Understanding farm diversity to promote agroecological transitions. Sustainability (Switzerland) 2018, 10, 4337, doi: 10.3390/su10124337.

133. Teschner, N.; Orenstein, D. E.; Shapira, I.; Keasar, T. Socio-ecological research and the transition toward sustainable agriculture. International Journal of Agricultural Sustainability 2017, 15, 99-101, doi: 10.1080/14735903.2017.1294841.

134. Uden, D. R.; Allen, C. R.; Munoz-Arriola, F.; Ou, G.; Shank, N. A framework for tracing social-ecological trajectories and traps in intensive agricultural landscapes. Sustainability (Switzerland) 2018, 10, 1646, doi: 10.3390/su10051646.

135. Van Bers, C.; Robinson, J. B. Farming in 2031: A scenario of sustainable agriculture in canada. Journal of Sustainable Agriculture 1994, 4, 41-65, doi: 10.1300/J064v04n01_05.

136. Van der Windt, H. J.; Swart, J. A. A. Aligning nature conservation and agriculture: the search for new regimes. Restoration Ecology 2018, 26, S54-S62, doi: 10.1111/rec.12570.

137. Vankeerberghen, A.; Stassart, P. M. The transition to conservation agriculture: an insularization process towards sustainability. International Journal of Agricultural Sustainability 2016, 14, 392-407, doi: 10.1080/14735903.2016.1141561.

138. Veldkamp, A.; Van Altvorst, A. C.; Eweg, R.; Jacobsen, E.; Van Kleef, A.; Van Latesteijn, H.; Mager, S.; Mommaas, H.; Smeets, P. J. A. M.; Spaans, L.; Van Trijp, J. C. M. Triggering transitions towards sustainable development of the Dutch agricultural sector: TransForum's approach. Agronomy for Sustainable Development 2009, 29, 87-96, doi: 10.1051/agro:2008022.

139. Vergine, P.; Salerno, C.; Libutti, A.; Beneduce, L.; Gatta, G.; Berardi, G.; Pollice, A. Closing the water cycle in the agro-industrial sector by reusing treated wastewater for irrigation. Journal of Cleaner Production 2017, 164, 587-596, doi: 10.1016/j.jclepro.2017.06.239.

140. Visioli, G.; Galieni, A.; Stagnari, F.; Bonas, U.; Speca, S.; Faccini, A.; Pisante, M.; Marmiroli, N. Proteomics of durum wheat grain during transition to conservation agriculture. PLoS ONE 2016, 11, e0156007, doi: 10.1371/journal.pone.0156007.

141. Viswanathan, P. K.; Thapa, G. B.; Routray, J. K.; Ahmad, M. M. Agrarian transition and emerging challenges in Asian agriculture: A critical assessment. Economic and Political Weekly 2012, 47, 41-50.

142. Vlahos, G.; Karanikolas, P.; Koutsouris, A. Integrated farming in Greece: A transitionto-sustainability perspective. International Journal of Agricultural Resources, Governance and Ecology 2017, 13, 43-59, doi: 10.1504/IJARGE.2017.084033.

143. Wang, J.; Chu, M.; Ma, Y. Measuring rice farmer's pesticide overuse practice and the determinants: A statistical analysis based on data collected in Jiangsu and Anhui provinces of China. Sustainability (Switzerland) 2018, 10, 677, doi: 10.3390/su10030677.

144. Weiler, A. M.; Otero, G.; Wittman, H. Rock Stars and Bad Apples: Moral Economies of Alternative Food Networks and Precarious Farm Work Regimes. Antipode 2016, 48, 1140-1162, doi: 10.1111/anti.12221.

145. Wezel, A.; Brives, H.; Casagrande, M.; Clément, C.; Dufour, A.; Vandenbroucke, P. Agroecology territories: places for sustainable agricultural and food systems and biodiversity conservation. Agroecology and Sustainable Food Systems 2016, 40, 132-144, doi: 10.1080/21683565.2015.1115799. 
146. Wezel, A.; Goris, M.; Bruil, J.; Félix, G. F.; Peeters, A.; Bàrberi, P.; Bellon, S.; Migliorini, P. Challenges and action points to amplify agroecology in Europe. Sustainability (Switzerland) 2018, 10, 1598, doi: 10.3390/su10051598.

147. Wigboldus, S.; Klerkx, L.; Leeuwis, C.; Schut, M.; Muilerman, S.; Jochemsen, H. Systemic perspectives on scaling agricultural innovations. A review. Agronomy for Sustainable Development 2016, 36, 46, doi: 10.1007/s13593-016-0380-z.

148. Williams, J.; Alter, T.; Shrivastava, P. Systemic governance of sustainable agriculture: Implementing sustainable development goals and climate-friendly farming. Outlook on Agriculture 2018, 47, 192-195, doi: 10.1177/0030727018795907.

149. Windhorst, H. W. Pigs and space: hog farming and pork production in the European Union and the United States in transition. Erdkunde 1998, 52, 232-249, doi: 10.3112 /erdkunde.1998.03.04.

150. Withers, P. J. A.; Rodrigues, M.; Soltangheisi, A.; De Carvalho, T. S.; Guilherme, L. R. G.; Benites, V. D. M.; Gatiboni, L. C.; De Sousa, D. M. G.; Nunes, R. D. S.; Rosolem, C. A.; Andreote, F. D.; Oliveira, A. D., Jr.; Coutinho, E. L. M.; Pavinato, P. S. Transitions to sustainable management of phosphorus in Brazilian agriculture. Scientific Reports 2018, 8, 2537, doi: 10.1038/s41598-018-20887-z.

151. Zaal, F.; Oostendorp, R. H. Explaining a miracle: Intensification and the transition towards sustainable small-scale agriculture in dryland Machakos and Kitui Districts, Kenya. World Development 2002, 30, 1271-1287, doi: 10.1016/S0305-750X(02)00030-X.

152. Zimmer, H. C.; Le Thi, H.; Lo, D.; Baynes, J.; Nichols, J. D. Why do farmers still grow corn on steep slopes in northwest Vietnam? Agroforestry Systems 2018, 92, 1721-1735, doi: 10.1007/s10457-017-0121-6.

153. Zwartkruis, J. V.; Berg, H.; Hof, A. F.; Kok, M. T. J. Agricultural nature conservation in the Netherlands: Three lenses on transition pathways. Technological Forecasting and Social Change 2020, 151, 119235, doi: 10.1016/j.techfore.2018.03.006.

\section{References}

1. Westley, F.; Olsson, P.; Folke, C.; Homer-Dixon, T.; Vredenburg, H.; Loorbach, D.; Thompson, J.; Nilsson, M.; Lambin, E.; Sendzimir, J.; et al. Tipping Toward Sustainability: Emerging Pathways of Transformation. Ambio 2011, 40, 762-780. [CrossRef]

2. Rockström, J.; Williams, J.; Daily, G.; Noble, A.; Matthews, N.; Gordon, L.; Wetterstrand, H.; DeClerck, F.; Shah, M.; Steduto, P.; et al. Sustainable intensification of agriculture for human prosperity and global sustainability. Ambio 2017, 46, 4-17. [CrossRef]

3. Velten, S.; Leventon, J.; Jager, N.; Newig, J. What Is Sustainable Agriculture? A Systematic Review. Sustainability 2015, 7, 7833-7865. [CrossRef]

4. Bennett, E.; Carpenter, S.R.; Gordon, L.J.; Ramankutty, N.; Balvanera, P.; Campbell, B.; Cramer, W.; Foley, J.; Folke, C.; Karlberg, L.; et al. Toward a More Resilient Agriculture. Solutions 2014, 5, 65-75.

5. Godfray, H.C.J.; Beddington, J.R.; Crute, I.R.; Haddad, L.; Lawrence, D.; Muir, J.F.; Pretty, J.; Robinson, S.; Thomas, S.M.; Toulmin, C. Food security: The challenge of feeding 9 billion people. Science 2010, 327, 812-818. [CrossRef] [PubMed]

6. $\quad$ Ramankutty, N.; Mehrabi, Z.; Waha, K.; Jarvis, L.; Kremen, C.; Herrero, M.; Rieseberg, L.H. Trends in Global Agricultural Land Use: Implications for Environmental Health and Food Security. Annu. Rev. Plant Biol. 2018, 69, 789-815. [CrossRef] [PubMed]

7. Bommarco, R.; Kleijn, D.; Potts, S.G. Ecological intensification: Harnessing ecosystem services for food security. Trends Ecol. Evol. 2013, 28, 230-238. [CrossRef] [PubMed]

8. Kates, R.W.; Parris, T.M. Long-term trends and a sustainability transition. Proc. Natl. Acad. Sci. USA 2003, 100, 8062-8067. [CrossRef]

9. Nakicenovic, N.; RockströM, J.; Gaffney, O.; Zimm, C. Global Commons in the Anthropocene: World Development on a Stable and Resilient Planet; Working Paper WP-16-019; International Institute for Applied Systems Analysis: Laxenburg, Austria, 2016.

10. Steffen, W.; Persson, Å.; Deutsch, L.; Zalasiewicz, J.; Williams, M.; Richardson, K.; Crumley, C.; Crutzen, P.; Folke, C.; Gordon, L.; et al. The anthropocene: From global change to planetary stewardship. Ambio 2011, 40, 739-761. [CrossRef]

11. United Nations. Resolution Adopted by the General Assembly on 25 September 2015 70/1; Transforming Our World: The 2030 Agenda for Sustainable Development; United Nations: New York, NY, USA, 2015.

12. Geels, F.W. From sectoral systems of innovation to socio-technical systems: Insights about dynamics and change from sociology and institutional theory. Res. Policy 2004, 33, 897-920. [CrossRef]

13. Kemp, R.; Loorbach, D.; Rotmans, J. Transition management as a model for managing processes of co-evolution towards sustainable development. Int. J. Sustain. Dev. World Ecol. 2007, 14, 78-91. [CrossRef] 
14. Geels, F.W. The multi-level perspective on sustainability transitions: Responses to seven criticisms. Environ. Innov. Soc. Transit. 2011, 1, 24-40. [CrossRef]

15. Geels, F.W.; Schot, J. Typology of sociotechnical transition pathways. Res. Policy 2007, 36, 399-417. [CrossRef]

16. El Bilali, H. Research on agro-food sustainability transitions: A systematic review of research themes and an analysis of research gaps. J. Clean. Prod. 2019, 221, 353-364. [CrossRef]

17. Weber, H.; Poeggel, K.; Eakin, H.; Fischer, D.; Lang, D.J.; von Wehrden, H.; Wiek, A. What are the ingredients for food systems change towards sustainability?-Insights from the literature. Environ. Res. Lett. 2020, 15, 113001. [CrossRef]

18. Windhorst, H.W. Pigs and space: Hog farming and pork production in the European Union and the United States in transition. Erdkunde 1998, 52, 232-249. [CrossRef]

19. Southavilay, B.; Nanseki, T.; Takeuchi, S. Analysis on policies and agricultural transition: Challenges in promoting sustainable agriculture in Northern Laos. J. Fac. Agric. Kyushu Univ. 2013, 58, 219-223.

20. Wigboldus, S.; Klerkx, L.; Leeuwis, C.; Schut, M.; Muilerman, S.; Jochemsen, H. Systemic perspectives on scaling agricultural innovations. A review. Agron. Sustain. Dev. 2016, 36. [CrossRef]

21. Doremus, H.; Dan Tarlock, A. Fish, Farms, and the Clash of Cultures in the Klamath Basin. Ecol. Law Q. 2003, 30, $279-350$.

22. Long, T.B.; Blok, V.; Coninx, I. Barriers to the adoption and diffusion of technological innovations for climate-smart agriculture in Europe: Evidence from The Netherlands, France, Switzerland and Italy. J. Clean. Prod. 2016, 112, 9-21. [CrossRef]

23. Lu, Y.C.; Kelly, T.C. Implications of sustainable agriculture for the world food situation. Food Rev. Int. 1995, 11, 255-280. [CrossRef]

24. Wezel, A.; Brives, H.; Casagrande, M.; Clément, C.; Dufour, A.; Vandenbroucke, P. Agroecology territories: Places for sustainable agricultural and food systems and biodiversity conservation. Agroecol. Sustain. Food Syst. 2016, 40, 132-144. [CrossRef]

25. Peters, C.J.; Picardy, J.A.; Darrouzet-Nardi, A.; Griffin, T.S. Feed conversions, ration compositions, and land use efficiencies of major livestock products in U.S. agricultural systems. Agric. Syst. 2014, 130, 35-43. [CrossRef]

26. Jacobi, J.; Llanque, A. "When we stand up, they have to negotiate with Us": Power relations in and between an agroindustrial and an indigenous food system in Bolivia. Sustainability 2018, 10, 4001. [CrossRef]

27. Vergine, P.; Salerno, C.; Libutti, A.; Beneduce, L.; Gatta, G.; Berardi, G.; Pollice, A. Closing the water cycle in the agro-industrial sector by reusing treated wastewater for irrigation. J. Clean. Prod. 2017, 164, 587-596. [CrossRef]

28. Järnberg, L.; Enfors Kautsky, E.; Dagerskog, L.; Olsson, P. Green niche actors navigating an opaque opportunity context: Prospects for a sustainable transformation of Ethiopian agriculture. Land Use Policy 2018, 71, 409-421. [CrossRef]

29. Tang, Q.; Bennett, S.J.; Xu, Y.; Li, Y. Agricultural practices and sustainable livelihoods: Rural transformation within the Loess Plateau, China. Appl. Geogr. 2013, 41, 15-23. [CrossRef]

30. Hill, S.B.; MacRae, R.J. Organic farming in Canada. Agric. Ecosyst. Environ. 1992, 39, 71-84. [CrossRef]

31. Macrae, R.J.; Hill, S.B.; Henning, J.; Bentley, A.J. Policies, programs, and regulations to support the transition to sustainable agriculture in Canada. Am. J. Altern. Agric. 1990, 5, 76-92. [CrossRef]

32. Van Bers, C.; Robinson, J.B. Farming in 2031: A scenario of sustainable agriculture in Canada. J. Sustain. Agric. 1994, 4, 41-65. [CrossRef]

33. Ruttan, V.W. The transition to agricultural sustainability. Proc. Natl. Acad. Sci. USA 1999, 96, 5960-5967. [CrossRef] [PubMed]

34. Koppel, B.; Zurick, D. Rural transformation and the future of agricultural development policy in Asia. Agric. Adm. Ext. 1988, 28, 283-301. [CrossRef]

35. Gómez, L.F.; Ríos-Osorio, L.; Eschenhagen, M.L. Agroecology publications and coloniality of knowledge. Agron. Sustain. Dev. 2013, 33, 355-362. [CrossRef]

36. Uden, D.R.; Allen, C.R.; Munoz-Arriola, F.; Ou, G.; Shank, N. A framework for tracing social-ecological trajectories and traps in intensive agricultural landscapes. Sustainability 2018, 10, 1646. [CrossRef]

37. Gingrich, S.; Marco, I.; Aguilera, E.; Padró, R.; Cattaneo, C.; Cunfer, G.; Guzmán, G.I.; MacFadyen, J.; Watson, A. Agroecosystem energy transitions in the old and new worlds: Trajectories and determinants at the regional scale. Reg. Environ. Chang. 2018, 18, 1089-1101. [CrossRef]

38. Chantre, E.; Cardona, A. Trajectories of French Field Crop Farmers Moving Toward Sustainable Farming Practices: Change, Learning, and Links with the Advisory Services. Agroecol. Sustain. Food Syst. 2014, 38, 573-602. [CrossRef]

39. Vankeerberghen, A.; Stassart, P.M. The transition to conservation agriculture: An insularization process towards sustainability. Int. J. Agric. Sustain. 2016, 14, 392-407. [CrossRef]

40. Santhanam-Martin, M.; Ayre, M.; Nettle, R. Community sustainability and agricultural landscape change: Insights into the durability and vulnerability of the productivist regime. Sustain. Sci. 2015, 10, 207-217. [CrossRef]

41. Gaudino, S.; Reidsma, P.; Kanellopoulos, A.; Sacco, D.; van Ittersum, M.K. Integrated assessment of the EU's greening reform and feed self-sufficiency scenarios on dairy farms in Piemonte, Italy. Agriculture 2018, 8, 137. [CrossRef]

42. Hubeau, M.; Marchand, F.; Coteur, I.; Mondelaers, K.; Debruyne, L.; Van Huylenbroeck, G. A new agri-food systems sustainability approach to identify shared transformation pathways towards sustainability. Ecol. Econ. 2017, 131, 52-63. [CrossRef]

43. Sharma, T.; Carmichael, J.; Klinkenberg, B. Integrated modeling for exploring sustainable agriculture futures. Futures 2006, 38, 93-113. [CrossRef]

44. Sharma, T.; Carmichael, J.; Klinkenberg, B. A spatially explicit modeling approach to explore scenarios of sustainable agriculture futures. J. Indian Soc. Remote Sens. 2005, 33, 353-363. [CrossRef] 
45. Zwartkruis, J.V.; Berg, H.; Hof, A.F.; Kok, M.T.J. Agricultural nature conservation in The Netherlands: Three lenses on transition pathways. Technol. Forecast. Soc. Chang. 2020, 151, 119235. [CrossRef]

46. Plumecocq, G.; Debril, T.; Duru, M.; Magrini, M.B.; Sarthou, J.P.; Therond, O. The plurality of values in sustainable agriculture models: Diverse lock-in and coevolution patterns. Ecol. Soc. 2018, 23, 21. [CrossRef]

47. El Bilali, H. Transition heuristic frameworks in research on agro-food sustainability transitions. Environ. Dev. Sustain. 2020, 22, 1693-1728. [CrossRef]

48. Schot, J.; Geels, F.W. Strategic niche management and sustainable innovation journeys. theory, findings, research agenda, and policy. Technol. Anal. Strateg. Manag. 2008, 20, 537-554. [CrossRef]

49. Markard, J.; Raven, R.; Truffer, B. Sustainability transitions: An emerging field of research and its prospects. Res. Policy 2012, 41, 955-967. [CrossRef]

50. Loorbach, D. Transition management for sustainable development: A prescriptive, complexity-based governance framework. Governance 2010, 23, 161-183. [CrossRef]

51. Rotmans, J.; Loorbach, D. Transition management: Reflexive Governance of Societal Complexity Through Searching, Learning and Experimenting. In Managing the Transition to Renewable Energy: Theory and Practice from Local, Regional and Macro Perspectives; van den Bergh, J.C.J.M., Bruinsma, F.R., Eds.; Edward Elgar Publishing: Cheltenham, UK; Northampton, MA, USA, 2008 ; pp. 15-46.

52. Audet, R.; Lefèvre, S.; Brisebois, É.; El-Jed, M. Structuring tensions and key relations of montreal seasonal food markets in the sustainability transition of the agri-food sector. Sustainability 2017, 9, 320. [CrossRef]

53. Bui, S.; Cardona, A.; Lamine, C.; Cerf, M. Sustainability transitions: Insights on processes of niche-regime interaction and regime reconfiguration in agri-food systems. J. Rural Studies 2016, 48, 92-103. [CrossRef]

54. Ingram, J.; Maye, D.; Kirwan, J.; Curry, N.; Kubinakova, K. Interactions between Niche and Regime: An Analysis of Learning and Innovation Networks for Sustainable Agriculture across Europe. J. Agric. Educ. Ext. 2015, 21, 55-71. [CrossRef]

55. Isgren, E.; Ness, B. Agroecology to promote just sustainability transitions: Analysis of a civil society network in the Rwenzori region, western Uganda. Sustainability 2017, 9, 1357. [CrossRef]

56. Pigford, A.A.E.; Hickey, G.M.; Klerkx, L. Beyond agricultural innovation systems? Exploring an agricultural innovation ecosystems approach for niche design and development in sustainability transitions. Agric. Syst. 2018, 164, 116-121. [CrossRef]

57. Meynard, J.M.; Jeuffroy, M.H.; Le Bail, M.; Lefèvre, A.; Magrini, M.B.; Michon, C. Designing coupled innovations for the sustainability transition of agrifood systems. Agric. Syst. 2017, 157, 330-339. [CrossRef]

58. Konefal, J. Governing sustainability transitions: Multi-stakeholder initiatives and regime change in United States agriculture. Sustainability 2015, 7, 612-633. [CrossRef]

59. Cross, R.; Ampt, P. Exploring Agroecological Sustainability: Unearthing Innovators and Documenting a Community of Practice in Southeast Australia. Soc. Nat. Resour. 2017, 30, 585-600. [CrossRef]

60. Vlahos, G.; Karanikolas, P.; Koutsouris, A. Integrated farming in Greece: A transition-to-sustainability perspective. Int. J. Agric. Resour. Gov. Ecol. 2017, 13, 43-59. [CrossRef]

61. Massicotte, M.J.; Kelly-Bisson, C. What's wrong with permaculture design courses? Brazilian lessons for agroecological movementbuilding in Canada. Agric. Hum. Values 2019, 36, 581-594. [CrossRef]

62. Davidson, D.J.; Jones, K.E.; Parkins, J.R. Food safety risks, disruptive events and alternative beef production: A case study of agricultural transition in Alberta. Agric. Hum. Values 2016, 33, 359-371. [CrossRef]

63. Van der Windt, H.J.; Swart, J.A.A. Aligning nature conservation and agriculture: The search for new regimes. Restor. Ecol. 2018, 26, S54-S62. [CrossRef]

64. Huttunen, S.; Oosterveer, P. Transition to Sustainable Fertilisation in Agriculture, A Practices Approach. Sociol. Rural. 2017, 57, 191-210. [CrossRef]

65. Ollivier, G.; Magda, D.; Mazé, A.; Plumecocq, G.; Lamine, C. Agroecological transitions: What can sustainability transition frameworks teach us? an ontological and empirical analysis. Ecol. Soc. 2018, 23, 5. [CrossRef]

66. Martin, G.; Allain, S.; Bergez, J.E.; Burger-Leenhardt, D.; Constantin, J.; Duru, M.; Hazard, L.; Lacombe, C.; Magda, D.; Magne, M.A.; et al. How to address the sustainability transition of farming systems? A conceptual framework to organize research. Sustainability 2018, 10, 2083. [CrossRef]

67. Lamine, C.; Garçon, L.; Brunori, G. Territorial agrifood systems: A Franco-Italian contribution to the debates over alternative food networks in rural areas. J. Rural Stud. 2019, 68, 159-170. [CrossRef]

68. Grin, J. The politics of transition governance in Dutch agriculture. Conceptual understanding and implications for transition management. Int. J. Sustain. Dev. 2012, 15, 72-89. [CrossRef]

69. Hubeau, M.; Marchand, F.; Van Huylenbroeck, G. Sustainability experiments in the agri-food system: Uncovering the factors of new governance and collaboration success. Sustainability 2017, 9, 1027. [CrossRef]

70. Dentoni, D.; Waddell, S.; Waddock, S. Pathways of transformation in global food and agricultural systems: Implications from a large systems change theory perspective. Curr. Opin. Environ. Sustain. 2017, 29, 8-13. [CrossRef]

71. Pretty, J.N. Sustainable Agriculture, people and the resource base: Impacts on food production. Forum Dev. Studies 1997, 24, 7-32. [CrossRef]

72. Guthman, J. Thinking inside the neoliberal box: The micro-politics of agro-food philanthropy. Geoforum 2008, $39,1241-1253$. [CrossRef] 
73. Öhlund, E.; Zurek, K.; Hammer, M. Towards Sustainable Agriculture? The EU framework and local adaptation in Sweden and Poland. Environ. Policy Gov. 2015, 25, 270-287. [CrossRef]

74. Kanchanaroek, Y.; Aslam, U. Policy schemes for the transition to sustainable agriculture-Farmer preferences and spatial heterogeneity in northern Thailand. Land Use Policy 2018, 78, 227-235. [CrossRef]

75. DeLonge, M.S.; Miles, A.; Carlisle, L. Investing in the transition to sustainable agriculture. Environ. Sci. Policy 2016, 55, 266-273. [CrossRef]

76. Miles, A.; DeLonge, M.S.; Carlisle, L. Triggering a positive research and policy feedback cycle to support a transition to agroecology and sustainable food systems. Agroecol. Sustain. Food Syst. 2017, 41, 855-879. [CrossRef]

77. Pimbert, M.P.; Moeller, N.I. Absent agroecology aid: On UK agricultural development assistance since 2010. Sustainability 2018, 10, 505. [CrossRef]

78. Martin, E.; Fahey, B. The interorganizational challenge of agricultural reform in Bosnia and Herzegovina. South East Eur. J. Econ. Bus. 2009, 4, 7-22. [CrossRef]

79. Migliorini, P.; Gkisakis, V.; Gonzalvez, V.; Raigón, M.D.; Bàrberi, P. Agroecology in mediterranean Europe: Genesis, state and perspectives. Sustainability 2018, 10, 2724. [CrossRef]

80. Dwyer, J. Transformation for sustainable agriculture: What role for the second pillar of CAP? Bio-Based Appl. Econ. 2013, 2, 29-47.

81. Honig, M.; Petersen, S.; Shearing, C.; Pintér, L.; Kotze, I. The conditions under which farmers are likely to adapt their behaviour: A case study of private land conservation in the Cape Winelands, South Africa. Land Use Policy 2015, 48, 389-400. [CrossRef]

82. Coquil, X.; Dedieu, B.; Béguin, P. Professional transitions towards sustainable farming systems: The development of farmers' professional worlds. Work 2017, 57, 325-337. [CrossRef]

83. Meek, D. The cultural politics of the agroecological transition. Agric. Hum. Values 2016, 33, 275-290. [CrossRef]

84. Ingram, J.; Morris, C. The knowledge challenge within the transition towards sustainable soil management: An analysis of agricultural advisors in England. Land Use Policy 2007, 24, 100-117. [CrossRef]

85. Pant, L.P. Critical systems of learning and innovation competence for addressing complexity in transformations to agricultural sustainability. Agroecol. Sustain. Food Syst. 2014, 38, 336-365. [CrossRef]

86. Rasmussen, J.; Kaltoft, P. Alternative versus conventional attitudes in higher agricultural education. Biol. Agric. Hortic. 2003, 20, 347-363. [CrossRef]

87. Ahmed, S.; Sclafani, A.; Aquino, E.; Kala, S.; Barias, L.; Eeg, J. Building student capacity to lead sustainability transitions in the food system through farm-based authentic research modules in sustainability sciences (FARMS). Elem. Sci. Anthr. 2017, 5, 46. [CrossRef]

88. Sherwood, S.; van Bommel, S.; Paredes, M. Self-organization and the bypass: Re-imagining institutions for more sustainable development in agriculture and food. Agriculture 2016, 6, 66. [CrossRef]

89. Allaire, F.; Stinner, B.; Stinner, D.; Hartzler, J.; Moore, R.; Hoy, C.; Dorsey, J.; Hitzhusen, F.; Weaver, M. Learning sustainable development with a farm enterprise and its community. J. Sustain. Agric. 2001, 19, 65-83. [CrossRef]

90. Eksvärd, K.; Rydberg, T. Integrating Participatory Learning and Action Research and Systems Ecology: A Potential for Sustainable Agriculture Transitions. Syst. Pract. Action Res. 2010, 23, 467-486. [CrossRef]

91. Eksvärd, K. Facilitating Systemic Research and Learning and the transition to agricultural sustainability. J. Agric. Educ. Ext. 2010, 16, 265-280. [CrossRef]

92. Šūmane, S.; Kunda, I.; Knickel, K.; Strauss, A.; Tisenkopfs, T.; Rios, I.D.I.; Rivera, M.; Chebach, T.; Ashkenazy, A. Local and farmers' knowledge matters! How integrating informal and formal knowledge enhances sustainable and resilient agriculture. J. Rural Studies 2018, 59, 232-241. [CrossRef]

93. Teixeira, H.M.; van den Berg, L.; Cardoso, I.M.; Vermue, A.J.; Bianchi, F.J.J.A.; Peña-Claros, M.; Tittonell, P. Understanding farm diversity to promote agroecological transitions. Sustainability 2018, 10, 4337. [CrossRef]

94. Coquil, X.; Cerf, M.; Auricoste, C.; Joannon, A.; Barcellini, F.; Cayre, P.; Chizallet, M.; Dedieu, B.; Hostiou, N.; Hellec, F.; et al. Questioning the work of farmers, advisors, teachers and researchers in agro-ecological transition. A review. Agron. Sustain. Dev. 2018, 38, 47. [CrossRef]

95. Manuel-Navarrete, D.; Gallopín, G.C. Feeding the world sustainably: Knowledge governance and sustainable agriculture in the Argentine Pampas. Environ. Dev. Sustain. 2012, 14, 321-333. [CrossRef]

96. Raeisi, A.; Bijani, M.; Chizari, M. The mediating role of environmental emotions in transition from knowledge to sustainable use of groundwater resources in Iran's agriculture. Int. Soil Water Conserv. Res. 2018, 6, 143-152. [CrossRef]

97. Hubeau, M.; Marchand, F.; Coteur, I.; Debruyne, L.; Van Huylenbroeck, G. A reflexive assessment of a regional initiative in the agri-food system to test whether and how it meets the premises of transdisciplinary research. Sustain. Sci. 2018, 13, 1137-1154. [CrossRef]

98. Cong, R.G.; Termansen, M. A bio-economic analysis of a sustainable agricultural transition using green biorefinery. Sci. Total Environ. 2016, 571, 153-163. [CrossRef]

99. Galán-Martín, Á.; Vaskan, P.; Antón, A.; Esteller, L.J.; Guillén-Gosálbez, G. Multi-objective optimization of rainfed and irrigated agricultural areas considering production and environmental criteria: A case study of wheat production in Spain. J. Clean. Prod. 2017, 140, 816-830. [CrossRef]

100. Goglio, P.; Smith, W.N.; Worth, D.E.; Grant, B.B.; Desjardins, R.L.; Chen, W.; Tenuta, M.; McConkey, B.G.; Williams, A.; Burgess, P. Development of Crop.LCA, an adaptable screening life cycle assessment tool for agricultural systems: A Canadian scenario assessment. J. Clean. Prod. 2018, 172, 3770-3780. [CrossRef] 
101. Notarnicola, B.; Sala, S.; Anton, A.; McLaren, S.J.; Saouter, E.; Sonesson, U. The role of life cycle assessment in supporting sustainable agri-food systems: A review of the challenges. J. Clean. Prod. 2017, 140, 399-409. [CrossRef]

102. Bos, M.G.; van den Bosch, H.; Diemont, H.; Keulen, H.; Lahr, J.; Meijerink, G.; Verhagen, A. Quantifying the sustainability of agriculture. Irrig. Drain. Syst. 2007, 21, 1-15. [CrossRef]

103. Hammond Wagner, C.; Cox, M.; Bazo Robles, J.L. Pesticide lock-in in small scale Peruvian agriculture. Ecol. Econ. 2016,129 , 72-81. [CrossRef]

104. Wang, J.; Chu, M.; Ma, Y. Measuring rice farmer's pesticide overuse practice and the determinants: A statistical analysis based on data collected in Jiangsu and Anhui provinces of China. Sustainability 2018, 10, 677. [CrossRef]

105. Kumar, V.; Mills, D.J.; Anderson, J.D.; Mattoo, A.K. An alternative agriculture system is defined by a distinct expression profile of select gene transcripts and proteins. Proc. Natl. Acad. Sci. USA 2004, 101, 10535-10540. [CrossRef] [PubMed]

106. Withers, P.J.A.; Rodrigues, M.; Soltangheisi, A.; De Carvalho, T.S.; Guilherme, L.R.G.; Benites, V.D.M.; Gatiboni, L.C.; De Sousa, D.M.G.; Nunes, R.D.S.; Rosolem, C.A.; et al. Transitions to sustainable management of phosphorus in Brazilian agriculture. Sci. Rep. 2018, 8, 2537. [CrossRef] [PubMed]

107. Hanson, J.C.; Kauffman, C.S.; Schauer, A. Attitudes and Practices of Sustainable Farmers, with pplications to Designing a Sustainable Agriculture Extension Program. J. Sustain. Agric. 1996, 6, 135-156. [CrossRef]

108. Christianson, L.; Tyndall, J. Seeking a dialogue: A targeted technology for sustainable agricultural systems in the American Corn Belt. Sustain. Sci. Pract. Policy 2011, 7, 70-77. [CrossRef]

109. El Bilali, H. Relation between innovation and sustainability in the agro-food system. Ital. J. Food Sci. 2018, 30, 200-225. [CrossRef]

110. El Bilali, H.; Allahyari, M.S. Transition towards sustainability in agriculture and food systems: Role of information and communication technologies. Inf. Process. Agric. 2018, 5, 456-464. [CrossRef]

111. Sixt, G.N.; Klerkx, L.; Griffin, T.S. Transitions in water harvesting practices in Jordan's rainfed agricultural systems: Systemic problems and blocking mechanisms in an emerging technological innovation system. Environ. Sci. Policy 2018, 84, 235-249. [CrossRef]

112. Veldkamp, A.; Van Altvorst, A.C.; Eweg, R.; Jacobsen, E.; Van Kleef, A.; Van Latesteijn, H.; Mager, S.; Mommaas, H.; Smeets, P.J.A.M.; Spaans, L.; et al. Triggering transitions towards sustainable development of the Dutch agricultural sector: TransForum's approach. Agron. Sustain. Dev. 2009, 29, 87-96. [CrossRef]

113. Pala, M.; Ryan, J.; Mazid, A.; Abdallah, O.; Nachit, M. Wheat farming in Syria: An approach to economic transformation and sustainability. Renew. Agric. Food Syst. 2004, 19, 30-34. [CrossRef]

114. Blesh, J.; Wolf, S.A. Transitions to agroecological farming systems in the Mississippi River Basin: Toward an integrated socioecological analysis. Agric. Hum. Values 2014, 31, 621-635. [CrossRef]

115. Fernandez, M.; Williams, J.; Figueroa, G.; Graddy-Lovelace, G.; MacHado, M.; Vazquez, L.; Perez, N.; Casimiro, L.; Romero, G.; Funes-Aguilar, F. New opportunities, new challenges: Harnessing Cuba's advances in agroecology and sustainable agriculture in the context of changing relations with the United States. Elem. Sci. Anthr. 2018, 6, 76. [CrossRef]

116. Wezel, A.; Goris, M.; Bruil, J.; Félix, G.F.; Peeters, A.; Bàrberi, P.; Bellon, S.; Migliorini, P. Challenges and action points to amplify agroecology in Europe. Sustainability 2018, 10, 1598. [CrossRef]

117. Palomo-Campesino, S.; González, J.A.; García-Llorente, M. Exploring the connections between agroecological practices and ecosystem services: A systematic literature review. Sustainability 2018, 10, 4339. [CrossRef]

118. Onaindia, M.; Peña, L.; de Manuel, B.F.; Rodríguez-Loinaz, G.; Madariaga, I.; Palacios-Agúndez, I.; Ametzaga-Arregi, I. Land use efficiency through analysis of agrological capacity and ecosystem services in an industrialized region (Biscay, Spain). Land Use Policy 2018, 78, 650-661. [CrossRef]

119. Su, S.; Jiang, Z.; Zhang, Q.; Zhang, Y. Transformation of agricultural landscapes under rapid urbanization: A threat to sustainability in Hang-Jia-Hu region, China. Appl. Geogr. 2011, 31, 439-449. [CrossRef]

120. Hirsch, D.; Meyer, C.H.; Klement, J.; Hamer, M.; Terlau, W. Urban agriculture and food systems dynamics in the German Bonn/Rhein-Sieg Region. Int. J. Food Syst. Dyn. 2016, 7, 341-359. [CrossRef]

121. Moschitz, H.; Moser, R.; Di Giulio, M. Urban agriculture: Stimulus for a sustainable transformation of city and countryside. GAIA 2017, 26, 65-67. [CrossRef]

122. Herrmann, D.L.; Chuang, W.C.; Schwarz, K.; Bowles, T.M.; Garmestani, A.S.; Shuster, W.D.; Eason, T.; Hopton, M.E.; Allen, C.R. Agroecology for the shrinking city. Sustainability 2018, 10, 675. [CrossRef]

123. Miralles, I.; Dentoni, D.; Pascucci, S. Understanding the organization of sharing economy in agri-food systems: Evidence from alternative food networks in Valencia. Agric. Hum. Values 2017, 34, 833-854. [CrossRef]

124. Oda, K.; Rupprecht, C.D.D.; Tsuchiya, K.; McGreevy, S.R. Urban agriculture as a sustainability transition strategy for shrinking cities? Land use change trajectory as an obstacle in Kyoto city, Japan. Sustainability 2018, 10, 1048. [CrossRef]

125. Poetz, K.; Haas, R.; Balzarova, M. Emerging strategic corporate social responsibility partnership initiatives in agribusiness: The case of the sustainable agriculture initiative. J. Chain Netw. Sci. 2012, 12, 151-165. [CrossRef]

126. Ross, R.B.; Pandey, V.; Ross, K.L. Sustainability and strategy in U.S. agri-food firms: An assessment of current practices. Int. Food Agribus. Manag. Rev. 2015, 18, 17-48. [CrossRef]

127. Langendahl, P.A.; Cook, M.; Potter, S. Sustainable innovation journeys: Exploring the dynamics of firm practices as part of transitions to more sustainable food and farming. Local Environ. 2016, 21, 105-123. [CrossRef]

128. Press, M.; Arnould, E.J.; Murray, J.B.; Strand, K. Ideological challenges to changing strategic orientation in commodity agriculture. J. Mark. 2014, 78, 103-119. [CrossRef] 
129. Meares, A.C. Making the transition from conventional to sustainable agriculture: Gender, social movement participation, and quality of life on the family farm. Rural Sociol. 1997, 62, 21-47. [CrossRef]

130. Coldwell, I. New farming masculinities: 'More than just shit-kickers', we're 'switched-on' farmers wanting to 'balance lifestyle, sustainability and coin'. J. Sociol. 2007, 43, 87-103. [CrossRef]

131. Peter, G.; Bell, M.M.; Jarnagin, S.; Bauer, D. Coming Back Across the Fence: Masculinity and the Transition to Sustainable Agriculture. Rural Sociol. 2000, 65, 215-233. [CrossRef]

132. Leslie, I.S. Queer Farmers: Sexuality and the Transition to Sustainable Agriculture. Rural Sociol. 2017, 82, 747-771. [CrossRef]

133. Galdeano-Gómez, E.; Pérez-Mesa, J.C.; Godoy-Durán, Á. The social dimension as a driver of sustainable development: The case of family farms in southeast Spain. Sustain. Sci. 2016, 11, 349-362. [CrossRef]

134. Nischalke, S.M.; Abebe, M.; Wondimagegnhu, B.A.; Kriesemer, S.K.; Beuchelt, T. Forgotten Forests? Food Potential of Ancient Coffee Forests and Agroforestry Systems in the Southwestern Ethiopian Mountains, Seen Through a Gender Lens. Mt. Res. Dev. 2017, 37, 254-262. [CrossRef]

135. Bennich, T.; Belyazid, S.; Kopainsky, B.; Diemer, A. Understanding the transition to a bio-based economy: Exploring dynamics linked to the agricultural sector in Sweden. Sustainability 2018, 10, 1504. [CrossRef]

136. Sarkar, S.F.; Poon, J.S.; Lepage, E.; Bilecki, L.; Girard, B. Enabling a sustainable and prosperous future through science and innovation in the bioeconomy at Agriculture and Agri-Food Canada. New Biotechnol. 2018, 40, 70-75. [CrossRef] [PubMed]

137. Weiler, A.M.; Otero, G.; Wittman, H. Rock Stars and Bad Apples: Moral Economies of Alternative Food Networks and Precarious Farm Work Regimes. Antipode 2016, 48, 1140-1162. [CrossRef]

138. Williams, J.; Alter, T.; Shrivastava, P. Systemic governance of sustainable agriculture: Implementing sustainable development goals and climate-friendly farming. Outlook Agric. 2018, 47, 192-195. [CrossRef] 